\title{
Induction of New Lactam Derivatives From the Endophytic Fungus Aplosporella javeedii Through an OSMAC Approach
}

\author{
Ying Gao', Fabian Stuhldreier ${ }^{2}$, Laura Schmitt ${ }^{2}$, Sebastian Wesselborg', Zhiyong Guo , \\ Kun Zou ${ }^{3}$, Attila Mándi ${ }^{4}$, Tibor Kurtán ${ }^{4}$, Zhen Liu ${ }^{1 *}$ and Peter Proksch ${ }^{1,3 *}$ \\ 1 Institute of Pharmaceutical Biology and Biotechnology, Heinrich Heine University Düsseldorf, Düsseldorf, Germany, \\ ${ }^{2}$ Institute of Molecular Medicine I, Medical Faculty, Heinrich Heine University Düsseldorf, Düsseldorf, Germany, ${ }^{3}$ Hubei Key \\ Laboratory of Natural Products Research and Development, College of Biological and Pharmaceutical Sciences, China \\ Three Gorges University, Yichang, China, ${ }^{4}$ Department of Organic Chemistry, University of Debrecen, Debrecen, Hungary
}

OPEN ACCESS

Edited by:

Rosa Durán-Patrón,

University of Cádiz, Spain

Reviewed by:

Prasat Kittakoop,

Chulabhorn Graduate Institute,

Thailand

Javier Moraga,

University of Cádiz, Spain

${ }^{*}$ Correspondence:

Zhen Liu

zhenfeizio@sina.com

Peter Proksch

proksch@uni-duesseldorf.de

Specialty section:

This article was submitted to

Microbiotechnology,

a section of the journal

Frontiers in Microbiology

Received: 31 August 2020

Accepted: 16 October 2020

Published: 04 November 2020

Citation:

Gao Y, Stuhldreier F, Schmitt L,

Wesselborg S, Guo Z, Zou K.

Mándi A, Kurtán T, Liu Z and

Proksch P (2020) Induction of New

Lactam Derivatives From

the Endophytic Fungus Aplosporella

javeedii Through an OSMAC

Approach

Front. Microbiol. 11:600983.

doi: 10.3389/fmicb.2020.600983
Fermentation of the endophytic fungus Aplosporella javeedii on solid rice medium in presence of either $3.5 \% \mathrm{NaNO}_{3}$ or $3.5 \%$ monosodium glutamate caused a significant change of the fungal metabolite pattern compared to fungal controls grown only on rice. Chemical investigation of the former fungal extracts yielded 11 new lactam derivatives, aplosporellins A-K (2-12), in addition to the known compound, pramanicin A (1). All of these compounds were not detected when the fungus was grown on rice medium without these activators thereby indicating the power of this OSMAC approach. The structures of the new compounds were elucidated by one- and two- dimensional NMR spectroscopy, DFT-NMR calculations and by mass spectrometry as well as by comparison with the literature whereas the absolute configuration of the lactam core was determined by TDDFT-ECD and OR calculations. Pramanicin A (1) showed strong cytotoxicity against human lymphoma (Ramos) and leukemia (Jurkat J16) cells with $\mathrm{IC}_{50}$ values of 4.7 and $4.4 \mu \mathrm{M}$, respectively. Mechanistic studies indicated that $\mathbf{1}$ activates caspase-3 and induces apoptotic cell death.

Keywords: Aplosporella javeedii, lactam derivatives, OSMAC approach, DFT-NMR, TDDFT-ECD, OR calculations, apoptosis

\section{INTRODUCTION}

Endophytic fungi have been proven to be important sources for bioprospecting for new pharmaceutical lead compounds (Frank et al., 2015; Ancheeva et al., 2018; Bohler et al., 2018; Rehberg et al., 2018). However, conventional screening of endophytes that had been cultivated under standard laboratory conditions often fails to reveal the full biosynthetic potential of fungi and leads to re-isolation of already known metabolites. Strategies to activate silent biosynthetic gene clusters that are not expressed using conventional fermentation methods include co-cultivation of fungi with bacteria or the so called OSMAC (One Strain Many Compounds) approach (Daletos et al., 2017). The OSMAC approach makes use of altering cultivation parameters such as medium composition (carbon/nitrogen ratio, salinity, metal ions), physical parameters (temperature, $\mathrm{pH}$, oxygen condition), or addition of enzyme inhibitors/inducers and biosynthetic precursors in order 
to activate silent biosynthetic gene clusters and to expand the metabolite pattern produced by endophytes (Bode et al., 2002; Pan et al., 2019). Recent successful examples of OSMAC application from our own group include: addition of $2 \%$ tryptophan to rice medium which led to the accumulation of a new strongly cytotoxic bismacrolactone by the endophytic fungus Trichocladium sp. (Tran-Cong et al., 2019), addition of a mixture of salts $\left(\mathrm{MgSO}_{4}, \mathrm{NaNO}_{3}\right.$, and $\left.\mathrm{NaCl}\right)$ to solid Czapek medium which induced accumulation of nine new secondary metabolites by the endophytic fungus Bulgaria inquinans (Ariantari et al., 2019), and the accumulation of new brominated tyrosine-derived alkaloids by the soil fungus Gymnascella dankaliensis caused by addition of $\mathrm{NaBr}$ to solid rice medium (Wang et al., 2016).

As a part of our ongoing studies on fungal endophytes, we investigated the endophytic fungus Aplosporella javeedii derived from Orychophragmus violaceus (L.) O. E. Schul (Brassicaceae). O. violaceus is used in the Traditional Medicine of China for dissipating swelling and for treating unknown pyrogenic infections (Medicinal Plant Images Database, 2007). Recent studies have found that the plant also shows hepatoprotective effects (Huo et al., 2017). Previous chemical investigations of the fungus $A$. javeedii grown on solid rice medium resulted in the isolation of six new antifungal polyketides, five sesterterpenes including two new compounds, as well as a new macrolide, with some of the metabolites exhibiting cytotoxic and antimicrobial activities (Gao et al., 2020a,b). Due to the pronounced chemical diversity of natural products obtained from this fungus, we have now conducted an OSMAC study which involved the addition of different salts including 3.5\% NaBr, 3.5\% NaCl, 3.5\% NaF, 3.5\% $\mathrm{KCl}, 3.5 \% \mathrm{NH}_{4} \mathrm{Cl}, 3.5 \%\left(\mathrm{NH}_{4}\right)_{2} \mathrm{SO}_{4}, 3.5 \% \mathrm{C}_{5} \mathrm{H}_{8} \mathrm{NNaO}_{4} \cdot \mathrm{H}_{2} \mathrm{O}$ (monosodium glutamate), 3.5\% $\mathrm{NaNO}_{3}, 3.5 \% \mathrm{Na}_{2} \mathrm{HPO}_{4}, 3.5 \%$ $\mathrm{K}_{2} \mathrm{HPO}_{4} \cdot 3 \mathrm{H}_{2} \mathrm{O}, 3.5 \% \mathrm{KH}_{2} \mathrm{PO}_{4}, 3.5 \% \mathrm{FeSO}_{4}, 3.5 \% \mathrm{ZnSO}_{4}$, or $3.5 \% \mathrm{MgSO}_{4}$ to solid rice medium. The selection of most of these salts was based on previous studies which indicated their usefulness for activation of non-transcribed biosynthetic gene clusters (Hammerschmidt et al., 2015; Wang et al., 2016, 2018; Ariantari et al., 2019). The most striking effects with regard to an alteration of the fungal metabolite pattern, however, were detected following addition of either $3.5 \% \mathrm{NaNO}_{3}$ or of $3.5 \%$ monosodium glutamate to solid rice medium compared to fungal control cultures lacking either of these activators (Figure 1). Chemical investigation of fungal extracts obtained from fermentation of $A$. javeedii in presence of either 3.5\% $\mathrm{NaNO}_{3}$ or of $3.5 \%$ monosodium glutamate led to the isolation of 11 new lactam derivatives, aplosporellins A-K (2-12), in addition to the known compound, pramanicin A (1) (Figure 2), all of which were not detected when the fungus was grown on rice medium without these activators. Herein we report the structure elucidation of the new metabolites and the pro-apoptotic activity of pramanicin A (1).

\section{MATERIALS AND METHODS}

\section{General Experimental Procedures}

A Perkin-Elmer-241 MC polarimeter was used to measure optical rotations. ECD spectra were recorded on a J-810 spectropolarimeter. One- and two-dimensional NMR spectra were recorded on a Bruker ARX 600 spectrometer. Mass spectra (ESI) were recorded with a Finnigan LCQ Deca mass spectrometer. A UHR-QTOF maxis 4G mass spectrometer (Bruker Daltonics) was used to record HRESIMS data. A Dionex UltiMate-3400SD system with a LPG-3400SD pump and a photodiode array detector (DAD 3000RS) as well as a separation column (Eurosphere-10 $\mathrm{C}_{18}, 125 \times 4 \mathrm{~mm}$, Knauer) were used for HPLC analysis. Detection wave lengths were set at 235, 254, 280, and $340 \mathrm{~nm}$. Semi-preparative HPLC analysis was performed with a Merck Hitachi Chromaster HPLC system (UV detector L7400; pump L7100; column Eurosphere-100 $\mathrm{C}_{18}$, $300 \times 8 \mathrm{~mm}$, Knauer; flow rate at $5 \mathrm{~mL} / \mathrm{min})$. Silica gel 60 M (0.04-0.063 mm, Macherey-Nagel) or Sephadex LH-20 were used for column chromatography. TLC plates precoated with silica gel $\mathrm{F}_{254}$ (Merck) were used to monitor isolation fractions. Distilled and spectral grade solvents were used for column chromatography and spectroscopic measurements, respectively.

\section{Fungal Material and Fermentation}

The fungus A. javeedii (ID code ZGB-B) was isolated from fresh, healthy stems of Orychophragmus violaceus (L.) O. E. Schul (Brassicaceae), collected in April 2018 in Beijing, China. Fungal identification was carried out according to a standard protocol as described previously (Kjer et al., 2010). The GenBank accession number is MN720704. The fungal strain is kept in the Institute of Pharmaceutical Biology and Biotechnology, Heinrich Heine University, Duesseldorf, Germany.

The fungus was cultivated in two $1 \mathrm{~L}$ Erlenmeyer flasks, of which each was filled with solid rice medium containing $100 \mathrm{~g}$ rice and $110 \mathrm{~mL}$ demineralized water. After autoclaving at $121^{\circ} \mathrm{C}$ for $20 \mathrm{~min}$ and cooling down to room temperature, the fungal strain that was preserved on the ager plats for a week was cut into pieces and added in each flask under sterile condition. The fermentation was maintained under static conditions at room temperature until the rice medium was completely overgrown by the fungus which lasted around 20 days (control cultivation). OSMAC cultivations were carried out following the same procedure by growing the fungus on solid rice medium containing 3.5\% $\mathrm{NaBr}$, 3.5\% NaCl, 3.5\% NaF, 3.5\% KCl, 3.5\% $\mathrm{NH}_{4} \mathrm{Cl}, 3.5 \%\left(\mathrm{NH}_{4}\right)_{2} \mathrm{SO}_{4}$, $3.5 \% \mathrm{C}_{5} \mathrm{H}_{8} \mathrm{NNaO}_{4} \cdot \mathrm{H}_{2} \mathrm{O}$ (monosodium glutamate), $3.5 \% \mathrm{NaNO}_{3}$, $3.5 \% \quad \mathrm{Na}_{2} \mathrm{HPO}_{4}, 3.5 \% \mathrm{~K}_{2} \mathrm{HPO}_{4} \cdot 3 \mathrm{H}_{2} \mathrm{O}, 3.5 \% \quad \mathrm{KH}_{2} \mathrm{PO}_{4}, 3.5 \%$ $\mathrm{FeSO}_{4}, 3.5 \% \mathrm{ZnSO}_{4}$, or 3.5\% $\mathrm{MgSO}_{4}$. Two flasks were used for each experiment and each flask contained $100 \mathrm{~g}$ rice, $110 \mathrm{~mL}$ demineralized water and $3.5 \mathrm{~g}$ salts. The usefulness of $3.5 \%$ salts in the OSMAC approach has been proved by previous experiments with other fungi (Hammerschmidt et al., 2015; Wang et al., 2016, 2018). Based on the chromatographic profiles obtained from the extractions of these fermentations, fungal cultivations with striking changes of metabolite patterns were selected for further investigation.

\section{Extraction and Isolation}

The fungal culture grown on solid rice medium with addition of $3.5 \% \mathrm{NaNO}_{3}$ or $3.5 \%$ monosodium glutamate was extracted with $800 \mathrm{~mL}$ EtOAc followed by evaporation to dryness to afford the crude extract. The obtained brown extracts from the 3.5\% 


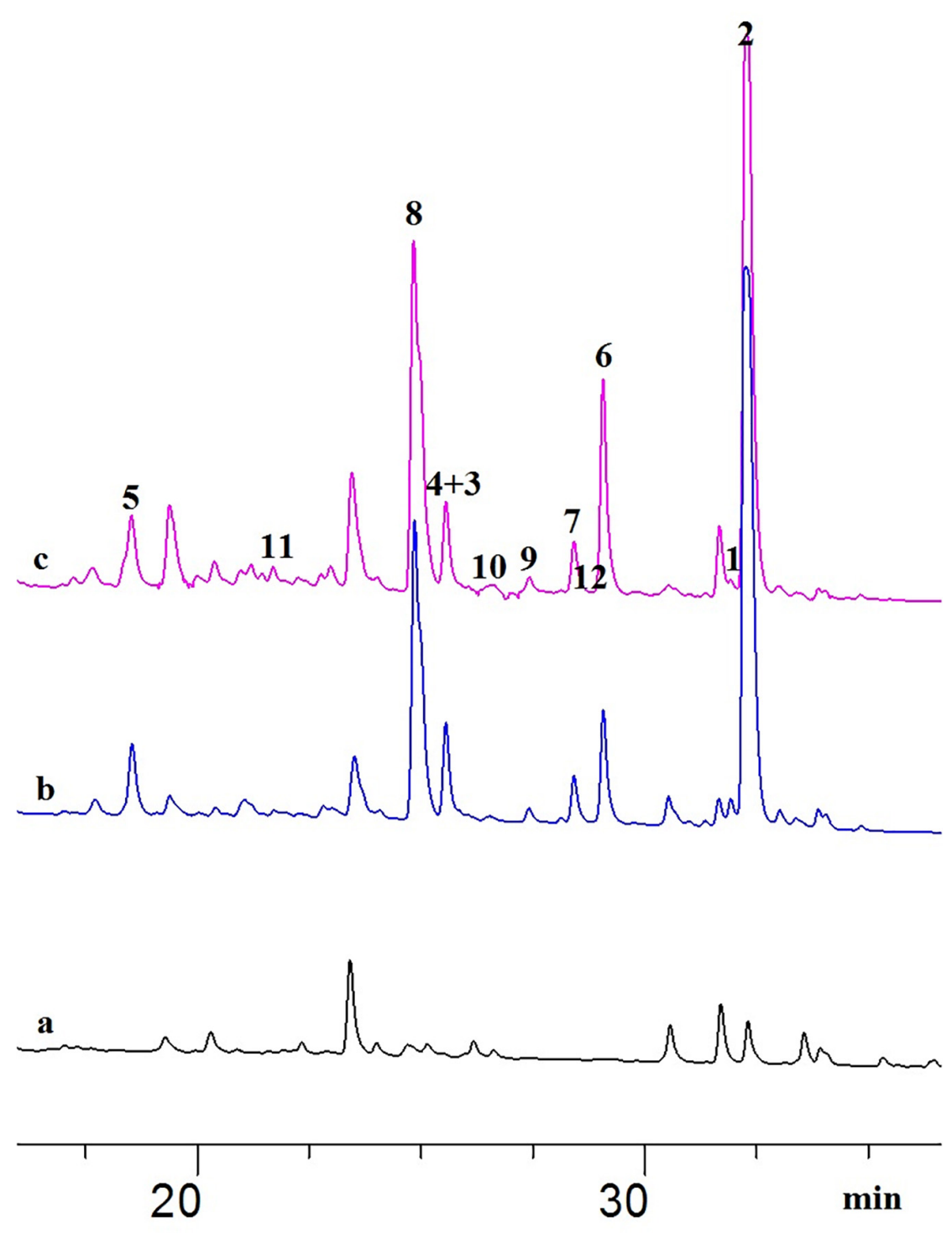

FIGURE 1 | HPLC chromatograms of the EtOAc extracts from OSMAC experiments detected at $235 \mathrm{~nm}$ : (A) A. javeedii control grown on solid rice medium; (B) A. javeedii cultured on solid rice medium with 3.5\% $\mathrm{NaNO}_{3}$; (C) A. javeedii cultured on solid rice medium with $3.5 \%$ monosodium glutamate.

$\mathrm{NaNO}_{3}$ and $3.5 \%$ monosodium glutamate cultures were 2.3 and $2.8 \mathrm{~g}$, respectively. The two crude extracts were subjected to a silica gel vacuum liquid chromatography (VLC) column, and eluted with 100\% n-hexane, $n$-hexane-EtOAc (9:1), $n$-hexaneEtOAc (1:1), $100 \%$ EtOAc, $\mathrm{CH}_{2} \mathrm{Cl}_{2}-\mathrm{MeOH}$ (1:1), and $100 \%$ $\mathrm{MeOH}$, respectively, which resulted in 6 fractions (V1 to V6) for each extract.

From the 3.5\% $\mathrm{NaNO}_{3}$ culture extract, fraction V5 (0.55 g) was subjected to a Sephadex LH-20 column using 100\% $\mathrm{MeOH}$ as eluent to give five subfractions (V5-S1 to V5-S5). Subfraction V5-S2 was then submitted to a RP-18 (40-63 $\mu \mathrm{m})$ vacuum liquid chromatography column and eluted with 5-100\% aqueous $\mathrm{MeOH}$ to yield 7 subfractions (V5-S2-RP1 to V5-S2-RP7). Subfraction V5-S2-RP4 was purified by semi-preparative HPLC using a mixture of $\mathrm{MeCN}$ and $\mathrm{H}_{2} \mathrm{O}$ (10:90) containing $0.1 \%$
$\mathrm{HCOOH}$ to give 4 (4.5 $\mathrm{mg}), \mathbf{8}(8.2 \mathrm{mg})$, and $\mathbf{1 1}$ (4.3 $\mathrm{mg})$. Subfraction V5-S2-RP5 was purified by semi-preparative HPLC using a gradient of $\mathrm{MeCN}$ and $\mathrm{H}_{2} \mathrm{O}$ (15:85 to 50:50) containing $0.1 \% \mathrm{HCOOH}$ to give $2(23.5 \mathrm{mg}), 3(5.1 \mathrm{mg}), 6(6.0 \mathrm{mg})$, and 7 (5.9 mg).

From the $3.5 \%$ monosodium glutamate culture extract, fraction V4 $(0.45 \mathrm{~g})$ was subjected to a Sephadex LH-20 column using $\mathrm{CH}_{2} \mathrm{Cl}_{2}-\mathrm{MeOH}(1: 1)$ as eluent to obtain three subfractions (V4-S1 to V4-S3). Subfraction V4-S2 was then submitted to RP-18 (40-63 $\mu \mathrm{m})$ vacuum liquid chromatography column and eluted with $10-100 \%$ aqueous $\mathrm{MeOH}$ to yield 10 subfractions (V4-S2-RP1 to V4-S2-RP10). Subfraction V4S2-RP5 was purified by semi-preparative HPLC using $\mathrm{MeOH}$ $0.1 \% \mathrm{HCOOH}$ in $\mathrm{H}_{2} \mathrm{O}$ (50:50 to $\left.72: 28\right)$ to give 10 (2.3 mg). Subfraction V4-S2-RP7 was purified by semi-preparative HPLC 


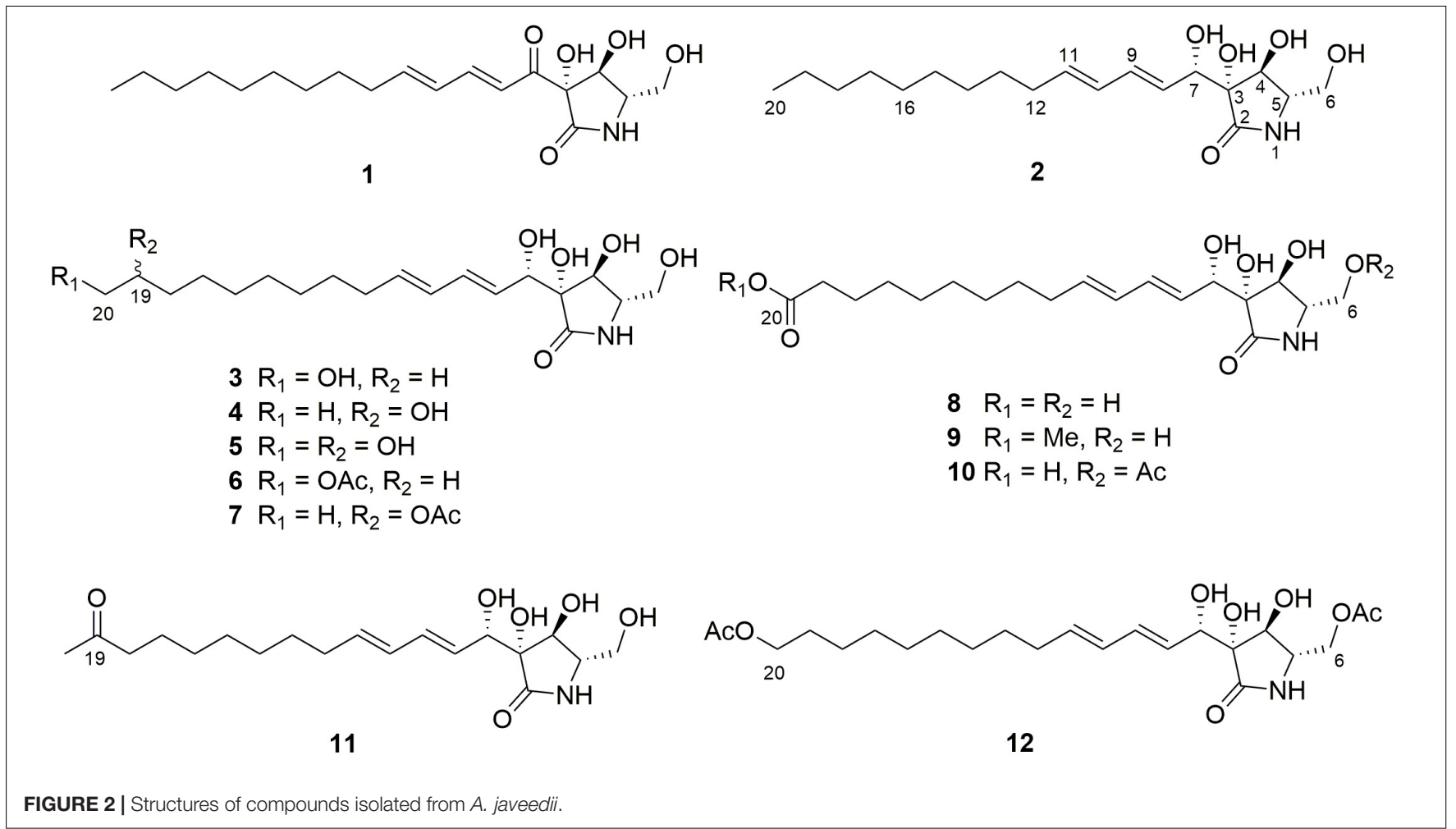

using $\mathrm{MeOH}-0.1 \% \mathrm{HCOOH}$ in $\mathrm{H}_{2} \mathrm{O}$ (65:35 to 86:14) to give $\mathbf{1}$ $(25 \mathrm{mg})$ and $12(1.4 \mathrm{mg})$. Fraction V5 $(0.68 \mathrm{~g})$ was subjected to a Sephadex LH-20 column using $100 \% \mathrm{MeOH}$ as eluent to obtain eight subfractions (V5-S1 to V5-S8). Subfraction V5-S4 was submitted to a RP-18 $(40-63 \mu \mathrm{m})$ vacuum liquid chromatography column and eluted with $10-100 \%$ aqueous $\mathrm{MeOH}$ to yield 10 subfractions (V5-S4-RP1 to V5-S4-RP10). Subfraction V5-S4-RP4 was purified by semi-preparative HPLC using $\mathrm{MeOH}-0.1 \% \mathrm{HCOOH}$ in $\mathrm{H}_{2} \mathrm{O}$ (50:50 to $70: 30$ ) to give $5(2.5 \mathrm{mg})$. Subfraction V5-S4-RP6 was purified by semipreparative HPLC using $\mathrm{MeOH}-0.1 \% \mathrm{HCOOH}$ in $\mathrm{H}_{2} \mathrm{O}$ (60:40) to give $\mathbf{9}(3.0 \mathrm{mg})$.

Pramanicin A (1): white solid; $[\alpha]^{20} \mathrm{D}-121(c 0.1, \mathrm{MeOH})$.

Aplosporellin A (2): Colorless oil; $[\alpha]^{20} \mathrm{D}-21(c 0.1, \mathrm{MeOH})$; $\mathrm{UV}(\mathrm{MeOH}) \lambda_{\max } 233 \mathrm{~nm}$; ECD $\lambda[\mathrm{nm}](\phi): 239(-1.54)$, 219 (1.06), 197 (-8.99); ${ }^{1} \mathrm{H}$ and ${ }^{13} \mathrm{C}$ NMR data, see Table 1; HRESIMS $[\mathrm{M}+\mathrm{Na}]^{+} \mathrm{m} / z 378.2252$ (calcd for $\mathrm{C}_{19} \mathrm{H}_{33} \mathrm{NNaO}_{5}$ 378.2251) (Supplementary Figures S1-S13).

Aplosporellin B (3): Colorless oil; $[\alpha]^{20}{ }_{D}-55(c 0.1, \mathrm{MeOH})$; $\mathrm{UV}(\mathrm{MeOH}) \lambda_{\max } 233 \mathrm{~nm}$; ECD $\lambda[\mathrm{nm}](\phi): 233(-7.06)$, $199(-8.83) ;{ }^{1} \mathrm{H}$ and ${ }^{13} \mathrm{C}$ NMR data, see Table 1; HRESIMS $[\mathrm{M}+\mathrm{Na}]^{+} m / z 394.2197$ (calcd for $\mathrm{C}_{19} \mathrm{H}_{33} \mathrm{NNaO}_{6} 394.2200$ ) (Supplementary Figures S14-S21).

Aplosporellin C (4): Colorless oil; $[\alpha]^{20} \mathrm{D}-26(c 0.1, \mathrm{MeOH})$; $\mathrm{UV}(\mathrm{MeOH}) \lambda_{\max } 234 \mathrm{~nm}$; ECD $\lambda[\mathrm{nm}](\phi): 233(-0.98)$, $197(-2.03) ;{ }^{1} \mathrm{H}$ and ${ }^{13} \mathrm{C}$ NMR data, see Table 2; HRESIMS $[\mathrm{M}+\mathrm{Na}]^{+} \mathrm{m} / z 394.2201$ (calcd for $\mathrm{C}_{19} \mathrm{H}_{33} \mathrm{NNaO}_{6}$ 394.2200) (Supplementary Figures S22-S29).

Aplosporellin D (5): Colorless oil; $[\alpha]^{20}{ }_{\mathrm{D}}-24(c 0.1, \mathrm{MeOH})$; UV (MeOH) $\lambda_{\max } 234 \mathrm{~nm} ;{ }^{1} \mathrm{H}$ and ${ }^{13} \mathrm{C}$ NMR data, see Table 2;
HRESIMS $[\mathrm{M}+\mathrm{Na}]^{+} \mathrm{m} / z 410.2145$ (calcd for $\mathrm{C}_{19} \mathrm{H}_{33} \mathrm{NNaO}_{7}$ 410.2149) (Supplementary Figures S30-S37).

Aplosporellin E (6): Colorless oil; $[\alpha]^{20}{ }_{\mathrm{D}}-33$ ( $\left.c 0.1, \mathrm{MeOH}\right)$; UV (MeOH) $\lambda_{\max } 233 \mathrm{~nm} ;{ }^{1} \mathrm{H}$ and ${ }^{13} \mathrm{C}$ NMR data, see Table 2; HRESIMS $[\mathrm{M}+\mathrm{Na}]^{+} \mathrm{m} / z 436.2307$ (calcd for $\mathrm{C}_{21} \mathrm{H}_{35} \mathrm{NNaO}_{7}$ 436.2306) (Supplementary Figures S38-S45).

Aplosporellin F (7): Colorless oil; $[\alpha]^{20}{ }_{\mathrm{D}}-36(c 0.1, \mathrm{MeOH})$; UV (MeOH) $\lambda_{\max } 234 \mathrm{~nm} ;{ }^{1} \mathrm{H}$ and ${ }^{13} \mathrm{C}$ NMR data, see Table 3; HRESIMS $[\mathrm{M}+\mathrm{Na}]^{+} \mathrm{m} / z 436.2304$ (calcd for $\mathrm{C}_{21} \mathrm{H}_{35} \mathrm{NNaO}_{7}$ 436.2306) (Supplementary Figures S46-S53).

Aplosporellin G (8): Colorless oil; $[\alpha]^{20}{ }_{D} \quad-57 \quad(c$ $0.1, \mathrm{MeOH}) ; \mathrm{UV}(\mathrm{MeOH}) \lambda_{\max } 233 \mathrm{~nm} ; \mathrm{ECD} \lambda[\mathrm{nm}]$ $(\phi): 234(-2.59), 197(-7.64) ;{ }^{1} \mathrm{H}$ and ${ }^{13} \mathrm{C}$ NMR data, see Table 3; HRESIMS $[\mathrm{M}+\mathrm{Na}]^{+} \mathrm{m} / z \quad 408.1990$ (calcd for $\mathrm{C}_{19} \mathrm{H}_{31} \mathrm{NNaO}_{7}$ 408.1993) (Supplementary Figures S54-S61).

Aplosporellin H (9): Colorless oil; $[\alpha]^{20}{ }_{\mathrm{D}}-26(c 0.1, \mathrm{MeOH})$; UV (MeOH) $\lambda_{\max } 232 \mathrm{~nm} ;{ }^{1} \mathrm{H}$ and ${ }^{13} \mathrm{C}$ NMR data, see Table 3; HRESIMS $[\mathrm{M}+\mathrm{Na}]^{+} \mathrm{m} / z 422.2150$ (calcd for $\mathrm{C}_{20} \mathrm{H}_{33} \mathrm{NNaO}_{7}$ 422.2149) (Supplementary Figures S62-S69).

Aplosporellin I (10): Colorless oil; $[\alpha]^{20}{ }_{\mathrm{D}}-31(c 0.1, \mathrm{MeOH})$; $\mathrm{UV}(\mathrm{MeOH}) \lambda_{\max } 233 \mathrm{~nm} ;{ }^{1} \mathrm{H}$ and ${ }^{13} \mathrm{C}$ NMR data, see Table 4; HRESIMS $[\mathrm{M}+\mathrm{Na}]^{+} \mathrm{m} / z 450.2102$ (calcd for $\mathrm{C}_{21} \mathrm{H}_{33} \mathrm{NNaO}_{8}$ 450.2098) (Supplementary Figures S70-S76).

Aplosporellin J (11): Colorless oil; $[\alpha]^{20}{ }_{\mathrm{D}}-7$ (c 0.1, $\left.\mathrm{MeOH}\right)$; $\mathrm{UV}(\mathrm{MeOH}) \lambda_{\max } 234 \mathrm{~nm} ;{ }^{1} \mathrm{H}$ and ${ }^{13} \mathrm{C}$ NMR data, see Table 4; HRESIMS $[\mathrm{M}+\mathrm{Na}]^{+} \mathrm{m} / z 392.2048$ (calcd for $\mathrm{C}_{19} \mathrm{H}_{31} \mathrm{NNaO}_{6}$ 392.2044) (Supplementary Figures S77-S84).

Aplosporellin K (12): Colorless oil; $[\alpha]^{20}{ }_{\mathrm{D}}-17$ (c 0.1, $\left.\mathrm{MeOH}\right)$; $\mathrm{UV}(\mathrm{MeOH}) \lambda_{\max } 232 \mathrm{~nm} ;{ }^{1} \mathrm{H}$ and ${ }^{13} \mathrm{C}$ NMR data, see Table 4; 
HRESIMS $[\mathrm{M}+\mathrm{Na}]^{+} m / z 478.2410$ (calcd for $\mathrm{C}_{23} \mathrm{H}_{37} \mathrm{NNaO}_{8}$ 478.2411) (Supplementary Figures S85-S91).

\section{Cytotoxicity and Apoptosis Assays}

Cytotoxicity against adult Burkitt's lymphoma B cells (Ramos, No. ACC-603) and lymphoblastic leukemia T cells (Jurkat J16, No. ACC-282) was tested as described previously (Harwoko et al., 2019). In the apoptosis assays, the protein kinase inhibitor staurosporine (STS, $2.5 \mu \mathrm{M}$, \#S5921, Sigma-Aldrich) was used as positive control, and standard growth medium supplemented with $0.1 \%$ DMSO was used as negative control. Determination of cell viability, western blot analysis and measurement of caspase3 activity were performed as described previously (Manns et al., 2011; Liu et al., 2017). All experiments were carried out in triplicate.

\section{Computational Methods}

Mixed torsional/low-mode conformational searches were carried out by means of the Macromodel 10.8.011 software using the MMFF with an implicit solvent model for $\mathrm{CHCl}_{3}$ applying a $21 \mathrm{~kJ} \mathrm{~mol}^{-1}$ energy window (MacroModel, 2015). Geometry reoptimizations of the resultant conformers [B3LYP/6$31+\mathrm{G}(\mathrm{d}, \mathrm{p})$ level in vacuo, $\omega \mathrm{B} 97 \mathrm{X} / \mathrm{TZVP}$ with PCM solvent model for MeCN and MeOH], DFT-NMR, TDDFT-ECD and SOR calculations were performed with Gaussian 09 (Frisch et al.,
2013). For NMR calculations the mPW1PW91/6-311 + G(2d,p) level while for the ECD and SOR calculations the B3LYP/TZVP, BH\&HLYP/TZVP, CAM-B3LYP/TZVP and PBE0/TZVP levels were applied with the same or no solvent model as in the preceding DFT optimization level. ECD spectra were generated as the sum of Gaussians with 4200 and $3000 \mathrm{~cm}^{-1}$ half-height widths, using dipole-velocity-computed rotational strengths (Stephens and Harada, 2010). Computed NMR shift data were corrected with $\mathrm{I}=-185.6277$ and $\mathrm{S}=-1.0175$ (Pierens, 2014). Boltzmann distributions were estimated from the B3LYP and the $\omega$ B97X energies. The MOLEKEL program was used for visualization of the results (Varetto, 2009).

\section{RESULTS}

\section{Chemical Identification of the Isolated Compounds}

Compound 2 was obtained as a colorless oil, with UV absorption at $\lambda_{\max } 233 \mathrm{~nm}$. Its molecular formula was established as $\mathrm{C}_{19} \mathrm{H}_{33} \mathrm{NO}_{5}$ on the basis of HRESIMS data, accounting for four degrees of unsaturation. The NMR spectra of 2 (Table 1) were recorded in methanol- $d_{4}$ as well as in DMSO- $d_{6}$. The latter solvent revealed the exchangeable protons of one $\mathrm{NH}$ proton

TABLE $1 \mid{ }^{1} \mathrm{H}$ and ${ }^{13} \mathrm{C}$ NMR data of compounds 2 and 3.

\begin{tabular}{|c|c|c|c|c|c|c|}
\hline No. & $2^{a}$ & & $2^{b}$ & & $3^{b}$ & \\
\hline & $\delta_{C}$, type & $\delta_{H}(J$ in $\mathrm{Hz})$ & $\delta_{C}$, type & $\delta_{H}(J$ in $H z)$ & $\delta_{C}$, type & $\delta_{H}(J$ in $\mathrm{Hz})$ \\
\hline 1 & $\mathrm{NH}$ & $7.69, \mathrm{br} s$ & & & & \\
\hline 2 & $174.4, \mathrm{C}$ & & 177.3, C & & $177.4, \mathrm{C}$ & \\
\hline 3 & $78.8, \mathrm{C}$ & & $80.8, \mathrm{C}$ & & $80.8, \mathrm{C}$ & \\
\hline 4 & $76.1, \mathrm{CH}$ & $3.89, \mathrm{t}(5.9)$ & $77.9, \mathrm{CH}$ & $4.12, d(6.6)$ & $78.0, \mathrm{CH}$ & $4.12, d(6.5)$ \\
\hline 5 & $59.5, \mathrm{CH}$ & 3.16, ddd $(5.9,5.5,3.5)$ & $61.2, \mathrm{CH}$ & 3.38, ddd $(6.6,5.8,3.2)$ & $61.2, \mathrm{CH}$ & 3.38, ddd $(6.5,5.8,3.3)$ \\
\hline 6 & $61.6, \mathrm{CH}_{2}$ & $\begin{array}{l}3.54, \text { ddd }(11.1,5.0,3.5) \\
3.30, \text { ddd }(11.1,5.5,5.0)\end{array}$ & $62.9, \mathrm{CH}_{2}$ & $\begin{array}{l}\text { 3.76, dd }(11.6,3.2) 3.52 \\
\text { dd }(11.6,5.8)\end{array}$ & $62.9, \mathrm{CH}_{2}$ & $\begin{array}{l}\text { 3.76, dd }(11.6,3.3) 3.52 \\
\text { dd }(11.6,5.8)\end{array}$ \\
\hline 7 & $73.0, \mathrm{CH}$ & 4.22, dd $(6.5,5.9)$ & $74.5, \mathrm{CH}$ & $4.43, d(7.1)$ & $74.6, \mathrm{CH}$ & $4.43, d(7.0)$ \\
\hline 8 & $130.8, \mathrm{CH}$ & $5.82, \mathrm{dd}(15.4,6.5)$ & 129.6, $\mathrm{CH}$ & $5.83, \mathrm{dd}(15.4,7.1)$ & 129.6, $\mathrm{CH}$ & $5.82, \mathrm{dd}(15.4,7.0)$ \\
\hline 9 & 131.0, CH & $6.14, \mathrm{dd}(15.4,10.6)$ & 134.6, $\mathrm{CH}$ & $6.32, \mathrm{dd}(15.4,10.4)$ & 134.6, $\mathrm{CH}$ & $6.32, \mathrm{dd}(15.4,10.5)$ \\
\hline 10 & $130.2, \mathrm{CH}$ & $6.00, \mathrm{dd}(15.1,10.6)$ & $131.2, \mathrm{CH}$ & $6.07, \mathrm{dd}(15.0,10.4)$ & $131.2, \mathrm{CH}$ & $6.07, \mathrm{dd}(15.0,10.5)$ \\
\hline 11 & 133.6, $\mathrm{CH}$ & $5.62, \mathrm{dt}(15.1,7.3)$ & 136.3, $\mathrm{CH}$ & $5.70, \mathrm{dt}(15.0,7.3)$ & 136.3, $\mathrm{CH}$ & 5.70, dt $(15.0,7.3)$ \\
\hline 12 & $32.0, \mathrm{CH}_{2}$ & $2.04, \mathrm{q}(7.3)$ & $33.7, \mathrm{CH}_{2}$ & $2.08, q(7.3)$ & 33.6, $\mathrm{CH}_{2}$ & $2.08, \mathrm{q}(7.3)$ \\
\hline 13 & $28.8, \mathrm{CH}_{2}$ & $1.34, \mathrm{~m}$ & $30.5, \mathrm{CH}_{2}$ & $1.39, \mathrm{~m}$ & $30.4, \mathrm{CH}_{2}$ & $1.39, \mathrm{~m}$ \\
\hline 14 & $29.0, \mathrm{CH}_{2}$ & $1.24, \mathrm{~m}$ & $30.7, \mathrm{CH}_{2}$ & $1.29, \mathrm{~m}$ & $30.7, \mathrm{CH}_{2}$ & $1.31, \mathrm{~m}$ \\
\hline 15 & $28.9, \mathrm{CH}_{2}$ & $1.24, \mathrm{~m}$ & 30.6, $\mathrm{CH}_{2}$ & 1.29, m & $30.6, \mathrm{CH}_{2}$ & $1.31, \mathrm{~m}$ \\
\hline 16 & $28.7, \mathrm{CH}_{2}$ & $1.24, \mathrm{~m}$ & $30.5, \mathrm{CH}_{2}$ & $1.29, \mathrm{~m}$ & $30.5, \mathrm{CH}_{2}$ & $1.31, \mathrm{~m}$ \\
\hline 17 & 28.6, $\mathrm{CH}_{2}$ & $1.24, \mathrm{~m}$ & $30.3, \mathrm{CH}_{2}$ & $1.29, \mathrm{~m}$ & 30.3, $\mathrm{CH}_{2}$ & $1.31, \mathrm{~m}$ \\
\hline 18 & $31.3, \mathrm{CH}_{2}$ & 1.23, m & $33.1, \mathrm{CH}_{2}$ & $1.28, \mathrm{~m}$ & 26.9, $\mathrm{CH}_{2}$ & $1.35, \mathrm{~m}$ \\
\hline 19 & $22.1, \mathrm{CH}_{2}$ & $1.25, \mathrm{~m}$ & 23.7, $\mathrm{CH}_{2}$ & $1.31, \mathrm{~m}$ & 33.7, $\mathrm{CH}_{2}$ & $1.52, \mathrm{~m}$ \\
\hline 20 & $13.9, \mathrm{CH}_{3}$ & $0.85, \mathrm{t}(6.9)$ & $14.4, \mathrm{CH}_{3}$ & $0.90, \mathrm{t}(7.0)$ & $63.0, \mathrm{CH}_{2}$ & $3.54, \mathrm{t}(6.7)$ \\
\hline $3-\mathrm{OH}$ & & $5.03, \mathrm{~s}$ & & & & \\
\hline $4-\mathrm{OH}$ & & $5.47, d(5.9)$ & & & & \\
\hline $6-\mathrm{OH}$ & & $4.74, \mathrm{t}(5.0)$ & & & & \\
\hline $7-\mathrm{OH}$ & & $4.75, d(5.9)$ & & & & \\
\hline
\end{tabular}

${ }^{a}$ Recorded at $600\left({ }^{1} \mathrm{H}\right)$ and $150 \mathrm{MHz}\left({ }^{13} \mathrm{C}\right)$ in DMSO-d $\cdot{ }^{b}$ Recorded at $600\left({ }^{1} \mathrm{H}\right)$ and $150 \mathrm{MHz}\left({ }^{13} \mathrm{C}\right)$ in $\mathrm{CD}_{3} \mathrm{OD}$. 
TABLE $2 \mid{ }^{1} \mathrm{H}$ and ${ }^{13} \mathrm{C}$ NMR data of compounds 4-6.

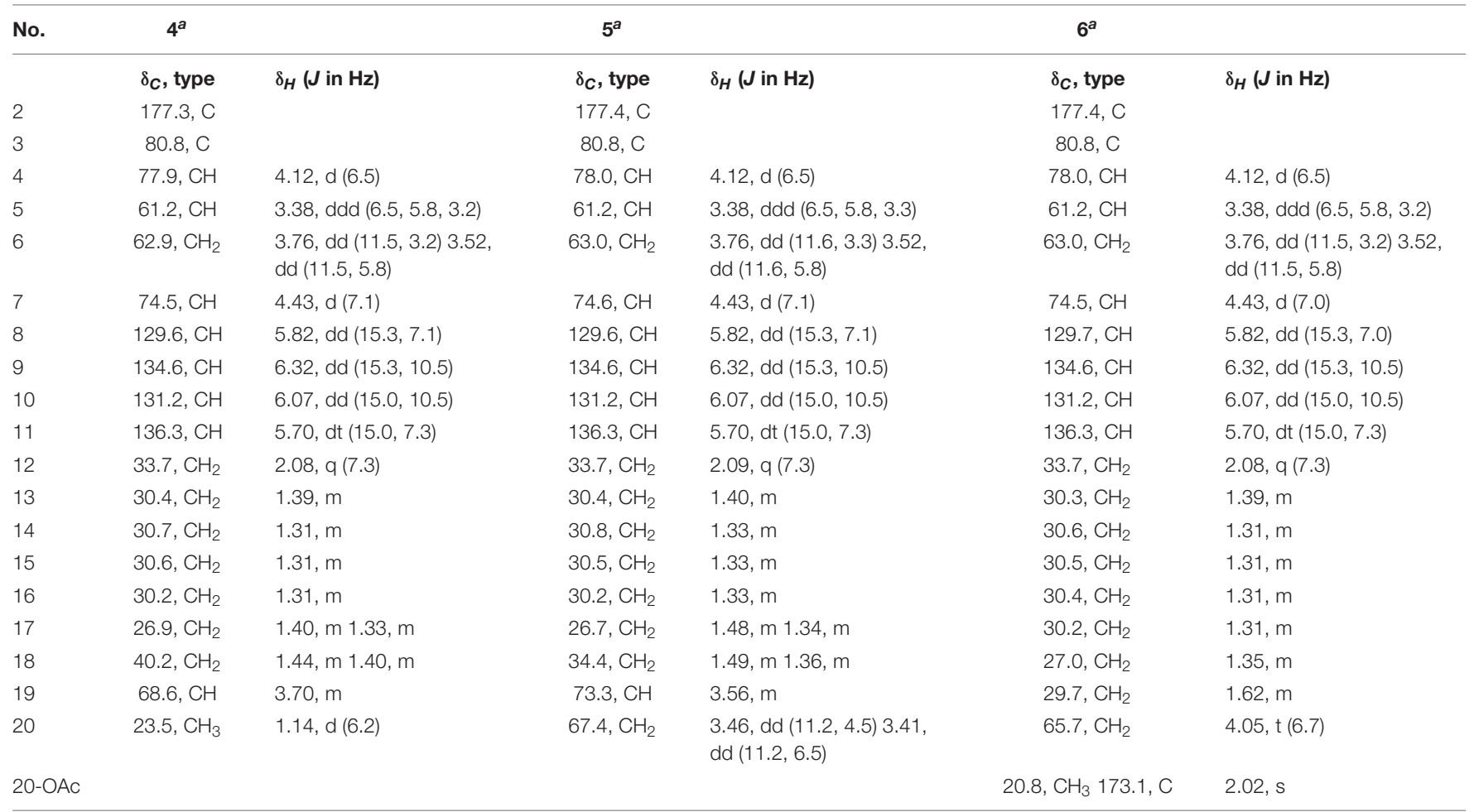

${ }^{a}$ Recorded at $600\left({ }^{1} \mathrm{H}\right)$ and $150 \mathrm{MHz}\left({ }^{13} \mathrm{C}\right)$ in $\mathrm{CD}_{3} \mathrm{OD}$.

TABLE $3 \mid{ }^{1} \mathrm{H}$ and ${ }^{13} \mathrm{C}$ NMR data of compounds 7-9.

\begin{tabular}{|c|c|c|c|c|c|c|}
\hline No. & $7^{a}$ & & $8^{a}$ & & $9^{a}$ & \\
\hline 2 & 177.3, C & & 177.3, C & & 177.3, C & \\
\hline 4 & 77.9, $\mathrm{CH}$ & $4.12, d(6.5)$ & $77.9, \mathrm{CH}$ & $4.12, d(6.6)$ & $78.0, \mathrm{CH}$ & $4.12, d(6.6)$ \\
\hline 5 & $61.2, \mathrm{CH}$ & 3.38, ddd $(6.5,5.8,3.2)$ & $61.1, \mathrm{CH}$ & 3.39, ddd $(6.6,5.8,3.2)$ & $61.2, \mathrm{CH}$ & 3.38, ddd $(6.6,5.8,3.3)$ \\
\hline 6 & $62.9, \mathrm{CH}_{2}$ & $\begin{array}{l}\text { 3.76, dd }(11.5,3.2) 3.52 \text {, } \\
\text { dd }(11.5,5.8)\end{array}$ & $62.9, \mathrm{CH}_{2}$ & $\begin{array}{l}\text { 3.76, dd (11.6, 3.2) 3.52, } \\
\text { dd }(11.6,5.8)\end{array}$ & 63.0, $\mathrm{CH}_{2}$ & $\begin{array}{l}\text { 3.76, dd }(11.5,3.3) 3.52 \\
d d(11.5,5.8)\end{array}$ \\
\hline 8 & $129.6, \mathrm{CH}$ & $5.83, \mathrm{dd}(15.3,7.1)$ & $129.5, \mathrm{CH}$ & $5.82, \mathrm{dd}(15.3,7.1)$ & $129.7, \mathrm{CH}$ & $5.82, \mathrm{dd}(15.4,7.0)$ \\
\hline 9 & 134.6, $\mathrm{CH}$ & $6.32, d d(15.3,10.5)$ & 134.6, $\mathrm{CH}$ & $6.32, \mathrm{dd}(15.3,10.5)$ & 134.6, $\mathrm{CH}$ & $6.32, \mathrm{dd}(15.4,10.6)$ \\
\hline 10 & $131.2, \mathrm{CH}$ & $6.07, \mathrm{dd}(15.1,10.5)$ & $131.2, \mathrm{CH}$ & $6.07, \mathrm{dd}(15.0,10.5)$ & $131.2, \mathrm{CH}$ & $6.07, \mathrm{dd}(15.0,10.6)$ \\
\hline 11 & 136.3, $\mathrm{CH}$ & $5.70, \mathrm{dt}(15.1,7.3)$ & 136.3, CH & 5.70, dt (15.0, 7.3) & 136.3, $\mathrm{CH}$ & 5.70, dt (15.0, 7.3) \\
\hline 12 & 33.6, $\mathrm{CH}_{2}$ & $2.08, q(7.3)$ & 33.6, $\mathrm{CH}_{2}$ & 2.08, q (7.3) & 33.7, $\mathrm{CH}_{2}$ & $2.08, q(7.3)$ \\
\hline 16 & $30.2, \mathrm{CH}_{2}$ & $1.31, \mathrm{~m}$ & $30.2, \mathrm{CH}_{2}$ & $1.32, \mathrm{~m}$ & $30.2, \mathrm{CH}_{2}$ & $1.31, \mathrm{~m}$ \\
\hline 17 & $26.5, \mathrm{CH}_{2}$ & $1.31, \mathrm{~m}$ & $30.1, \mathrm{CH}_{2}$ & $1.32, \mathrm{~m}$ & $30.1, \mathrm{CH}_{2}$ & $1.31, \mathrm{~m}$ \\
\hline 18 & $36.9, \mathrm{CH}_{2}$ & $1.58, \mathrm{~m} \mathrm{1.50, \textrm {m }}$ & $26.2, \mathrm{CH}_{2}$ & $1.59, \mathrm{~m}$ & 26.0, $\mathrm{CH}_{2}$ & $1.60, m$ \\
\hline 19 & $72.4, \mathrm{CH}$ & 4.86, m & $35.2, \mathrm{CH}_{2}$ & $2.27, \mathrm{t}(7.4)$ & $34.8, \mathrm{CH}_{2}$ & $2.31, \mathrm{t}(7.4)$ \\
\hline 20 & $20.2, \mathrm{CH}_{3}$ & $1.20, d(6.2)$ & 178.1, C & & 176.1, C & \\
\hline $19-O A C$ & $21.2, \mathrm{CH}_{3} 172.7, \mathrm{C}$ & $2.00, \mathrm{~s}$ & & & & \\
\hline 20-OMe & & & & & $52.0, \mathrm{CH}_{3}$ & $3.65, \mathrm{~s}$ \\
\hline
\end{tabular}

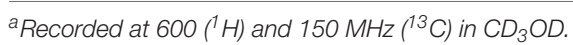


at $\delta_{\mathrm{H}} 7.69(\mathrm{NH}-1)$ as well as four $\mathrm{OH}$ protons at $\delta_{\mathrm{H}} 5.47$ (4$\mathrm{OH}), 5.03(3-\mathrm{OH}), 4.75(7-\mathrm{OH})$, and $4.74(6-\mathrm{OH})$. The ${ }^{13} \mathrm{C}$ NMR spectrum of 2 displayed one carbonyl group at $\delta_{C} 174.4$ (C2 ), and four olefinic carbons at $\delta_{C} 133.6$ (C-11), 131.0 (C-9), 130.8 (C-8), and 130.2 (C-10), accounting for three degrees of unsaturation. The presence of a $\gamma$-lactam ring was confirmed by the COSY correlations between $4-\mathrm{OH} / \mathrm{H}-4\left(\delta_{\mathrm{H}} 3.89\right) / \mathrm{H}-5\left(\delta_{\mathrm{H}}\right.$ $3.16) / \mathrm{H}_{2}-6\left(\delta_{\mathrm{H}} 3.54\right.$ and 3.30$) / 6-\mathrm{OH}$ and the HMBC correlations from NH-1 to C-3, C-4, and C-5, from 3-OH to C-2, C-3 and $\mathrm{C}-4$, from $4-\mathrm{OH}$ to $\mathrm{C}-3$, and from $\mathrm{H}-5$ to $\mathrm{C}-2$ (Figure 3 ). The COSY correlations between $\mathrm{H}-8\left(\delta_{\mathrm{H}} 5.82\right) / \mathrm{H}-9\left(\delta_{\mathrm{H}} 6.14\right) / \mathrm{H}-10$ $\left(\delta_{\mathrm{H}} 6.00\right) / \mathrm{H}-11\left(\delta_{\mathrm{H}} 5.62\right) / \mathrm{H}_{2}-12\left(\delta_{\mathrm{H}} 2.04\right) / \mathrm{H}_{2}-13\left(\delta_{\mathrm{H}} 1.34\right) / \mathrm{H}_{2}-14$ $\left(\delta_{\mathrm{H}} 1.24\right)$, and between Me-20 $\left(\delta_{\mathrm{H}} 0.85\right) / \mathrm{H}_{2}-19\left(\delta_{\mathrm{H}} 1.24\right)$ together with the HMBC correlations from Me-20 to C-19 $\left(\delta_{\mathrm{C}} 22.1\right)$ and C-18 $\left(\delta_{\mathrm{C}} 31.3\right)$ and the observation of characteristic aliphatic methylenes at 29.0, 28.9, 28.7, 28.6, and $\delta_{\mathrm{H}} 1.24\left(\mathrm{CH}_{2}-14,15,16\right.$, and 17), established the presence of a trideca-1,3-diene subunit in 2. In addition, the COSY correlations between $\mathrm{H}-8 / \mathrm{H}-7\left(\delta_{\mathrm{H}}\right.$ 4.22)/7- $\mathrm{OH}$ along with the $\mathrm{HMBC}$ correlations from $\mathrm{H}-7$ to $\mathrm{C}-2$, $\mathrm{C}-3$, and $\mathrm{C}-4$, and from $3-\mathrm{OH}$ to $\mathrm{C}-7$ indicated the trideca-1,3diene side chain to be connected to the $\gamma$-lactam moiety via the oxygenated carbon at C-7. Therefore, the planar structure of 2 was elucidated, which was similar to that of the co-isolated known compound, pramanicin A (1) (Schwartz et al., 1994; Harrison et al., 2000). The major difference between both compounds was the presence of an additional hydroxy group in $\mathbf{2}$ instead of the ketone group in $\mathbf{1}$ at position C-7. The trivial name aplosporellin A is proposed for $\mathbf{2}$.

The large values of $J_{8,9}(15.4 \mathrm{~Hz})$ and $J_{10,11}(15.1 \mathrm{~Hz})$ supported the $E$ configuration for the double bonds at C8/C-9 and C-10/C-11 in 2. The relative configuration of the $\gamma$-lactam ring was deduced through the ROESY spectrum and by comparison with pramanicin A (1) (Harrison et al., 2000), virgaricins A and B (Ishii et al., 2012, 2015). The NOE

TABLE $4 \mid{ }^{1} \mathrm{H}$ and ${ }^{13} \mathrm{C}$ NMR data of compounds $\mathbf{1 0 - 1 2 .}$

\begin{tabular}{|c|c|c|c|c|c|c|}
\hline No. & $10^{a}$ & & $11^{a}$ & & $12^{a}$ & \\
\hline 2 & 177.3, C & & 177.3, C & & $177.4, \mathrm{C}$ & \\
\hline 4 & $78.1, \mathrm{CH}$ & $4.10, d(6.8)$ & $77.9, \mathrm{CH}$ & $4.12, d(6.5)$ & $78.1, \mathrm{CH}$ & $4.10, d(6.7)$ \\
\hline 5 & $58.2, \mathrm{CH}$ & 3.55, ddd $(6.8,6.2,3.3)$ & $61.2, \mathrm{CH}$ & 3.38, ddd $(6.5,5.8,3.2)$ & $58.3, \mathrm{CH}$ & 3.55, ddd $(6.7,6.2,3.4)$ \\
\hline 6 & $65.0, \mathrm{CH}_{2}$ & $\begin{array}{l}\text { 4.30, dd (11.6, 3.3) 4.05, } \\
\text { dd (11.6, 6.2) }\end{array}$ & 63.0, $\mathrm{CH}_{2}$ & $\begin{array}{l}\text { 3.76, dd (11.6, 3.2) 3.52, } \\
\text { dd }(11.6,5.8)\end{array}$ & 65.0, $\mathrm{CH}_{2}$ & $\begin{array}{l}\text { 4.30, dd }(11.7,3.4) 4.04 \\
d d(11.7,6.2)\end{array}$ \\
\hline 8 & $129.4, \mathrm{CH}$ & $5.82, \mathrm{dd}(15.3,7.0)$ & 129.7, CH & $5.82, \mathrm{dd}(15.3,7.1)$ & $129.4, \mathrm{CH}$ & $5.82, \mathrm{dd}(15.4,7.1)$ \\
\hline 9 & $134.5, \mathrm{CH}$ & $6.32, \mathrm{dd}(15.3,10.5)$ & 134.6, $\mathrm{CH}$ & $6.32, \mathrm{dd}(15.3,10.5)$ & $134.5, \mathrm{CH}$ & 6.32, dd $(15.4,10.6)$ \\
\hline 10 & $131.2, \mathrm{CH}$ & $6.07, \mathrm{dd}(15.1,10.5)$ & $131.2, \mathrm{CH}$ & $6.07, \mathrm{dd}(15.0,10.5)$ & $131.2, \mathrm{CH}$ & $6.07, \mathrm{dd}(15.0,10.6)$ \\
\hline 11 & $136.3, \mathrm{CH}$ & $5.70, \mathrm{dt}(15.1,7.3)$ & 136.3, $\mathrm{CH}$ & $5.70, \mathrm{dt}(15.0,7.3)$ & 136.3, CH & 5.71 , dt $(15.0,7.3)$ \\
\hline 12 & 33.6, $\mathrm{CH}_{2}$ & 2.08, q (7.3) & 33.6, $\mathrm{CH}_{2}$ & $2.08, q(7.3)$ & 33.6, $\mathrm{CH}_{2}$ & 2.08, q (7.3) \\
\hline 16 & $30.2, \mathrm{CH}_{2}$ & $1.32, \mathrm{~m}$ & $30.1, \mathrm{CH}_{2}$ & $1.31, \mathrm{~m}$ & $30.4, \mathrm{CH}_{2}$ & $1.31, \mathrm{~m}$ \\
\hline 17 & $30.1, \mathrm{CH}_{2}$ & $1.32, \mathrm{~m}$ & $24.8, \mathrm{CH}_{2}$ & $1.54, \mathrm{~m}$ & $30.2, \mathrm{CH}_{2}$ & $1.31, \mathrm{~m}$ \\
\hline 18 & 26.7, $\mathrm{CH}_{2}$ & $1.59, \mathrm{~m}$ & 44.3, $\mathrm{CH}_{2}$ & $2.47, \mathrm{t}(7.3)$ & $27.0, \mathrm{CH}_{2}$ & $1.35, \mathrm{~m}$ \\
\hline 19 & 36.6, $\mathrm{CH}_{2}$ & $2.22, \mathrm{t}(7.4)$ & 212.3, C & & 29.6, $\mathrm{CH}_{2}$ & $1.62, \mathrm{~m}$ \\
\hline 20 & 179.8, C & & $29.8, \mathrm{CH}_{3}$ & $2.13, \mathrm{~s}$ & $65.7, \mathrm{CH}_{2}$ & $4.05, \mathrm{t}(6.7)$ \\
\hline 6-OAc & $20.5, \mathrm{CH}_{3}$ 172.5, C & $2.07, \mathrm{~s}$ & & & 20.6, $\mathrm{CH}_{3} 172.4, \mathrm{C}$ & $2.07, \mathrm{~s}$ \\
\hline 20-OAC & & & & & 20.8, $\mathrm{CH}_{3}$ 173.0, C & $2.02, \mathrm{~s}$ \\
\hline
\end{tabular}

${ }^{a}$ Recorded at $600\left({ }^{1} \mathrm{H}\right)$ and $150 \mathrm{MHz}\left({ }^{13} \mathrm{C}\right)$ in $\mathrm{CD}_{3} \mathrm{OD} .{ }^{b}$ Data extracted from HSQC and HMBC spectra.

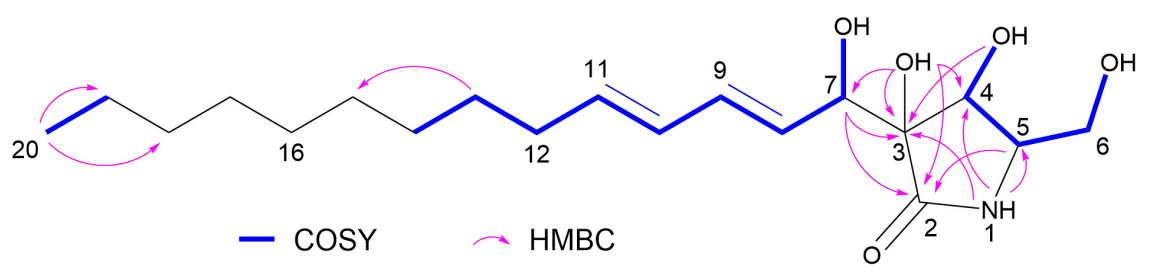

FIGURE 3 | COSY and key HMBC correlations of compound 2. 
correlations between $3-\mathrm{OH} / \mathrm{H}-4, \mathrm{H}-4 / \mathrm{H}_{2}-6$ indicated that $3-\mathrm{OH}$, $\mathrm{H}-4$ and $\mathrm{H}_{2}-6$ were located on the same side of the ring. In contrast, the NOE correlations between $\mathrm{H}-7 / 4-\mathrm{OH}, 4-\mathrm{OH} / \mathrm{H}-5$, indicated that $4-\mathrm{OH}$ and $\mathrm{H}-5$ were located on the opposite side compared to 3-OH, $\mathrm{H}-4$ and $\mathrm{H}_{2}-6$. On the basis of these findings, the relative stereochemistry of $\mathbf{2}$ in the $\gamma$-lactam moiety was assigned to be identical to that of pramanicin A (1).

Pramanicin A (1) was reported together with pramanicin from the fungus Stagonospora sp. (Schwartz et al., 1994), the latter contained an epoxide group at C-10/C-11 instead of a double bond. The absolute configuration of pramanicin A (1) was deduced by comparison to pramanicin through biogenetic considerations (Duspara et al., 1998; Harrison et al., 1998, 2000; Chen and Harrison, 2004) and by total synthesis (Cow et al., 1997; Barrett et al., 1999a,b; Tan et al., 2014, 2015, 2017), which confirmed that the compound has $(3 S, 4 S, 5 S)$ configuration. The large absolute value of the specific optical rotation (SOR) of 1 allowed testing the TDDFT-SOR method (Polavarapu, 2002; Mándi and Kurtán, 2019) and the $\omega B$ B7X functional (Chai and Head-Gordon, 2008; Bremond et al., 2016), which was also applied for the TDDFT-ECD calculations of 2. Merck Molecular Force Field (MMFF) conformational searches of $\mathbf{1}$ and the epimers of $\mathbf{2}$ resulted in a large number of conformers [c.a. 18 thousand by generating 100 thousand structures for $(3 R, 4 S, 5 S, 7 S)-2]$ and the searches were not complete, since many conformers were found only a few times (Mándi et al., 2015). Thus, model compounds were utilized for the calculations, in which the C-3 side-chain was truncated at the C-12 position (Figure 4).

The MMFF conformational search of $(3 S, 4 S, 5 S)-\mathbf{1 m o d}$ resulted in 79 conformers in a $21 \mathrm{~kJ} / \mathrm{mol}$ energy window, which were re-optimized at the $\omega \mathrm{B} 97 \mathrm{X} / \mathrm{TZVP} \mathrm{PCM} / \mathrm{MeOH}$ level yielding 16 low-energy conformers over $1 \%$ Boltzmanndistribution (Supplementary Figure S92). SOR values were computed at four levels (B3LYP/TZVP, BH\&HLYP/TZVP, CAMB3LYP/TZVP and PBE0/TZVP all with the PCM solvent model for $\mathrm{MeOH}$ ) and nice agreements were found with the experimental SOR value (computed SOR values in the range from -91 to -115 compared to the -121 experimental value) (Supplementary Table S1).

The absolute configuration of the $\gamma$-lactam ring of compound $\mathbf{2}$ is assumed to be identical to that of $\mathbf{1}$ based on biogenetic considerations whereas that of the $\mathrm{OH}$ group in the side chain at C-7 could not be elucidated. In order to solve this problem, DFT-NMR calculations were performed on the epimeric model compounds $(3 R, 4 S, 5 S, 7 R)$-2 mod and $(3 R, 4 S, 5 S, 7 S)$-2 mod (Lodewyk et al., 2012; Kicsák et al., 2018; Mándi and

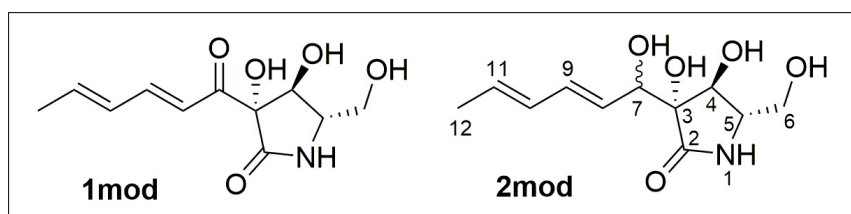

FIGURE 4 | Truncated model compounds applied for the SOR, NMR and ECD calculations.
Kurtán, 2019). B3LYP/6-31 + G(d,p) re-optimization of the initial 169 and 205 conformers resulted in 8 and 15 lowenergy conformers over $1 \%$ Boltzmann population, respectively (Supplementary Figures S93, S94). The ${ }^{13} \mathrm{C}$ NMR chemical shift data of $(3 R, 4 S, 5 S, 7 S)$-2 mod computed at the mPW1PW91/6$311+G(2 d, p)$ level reproduced much better the experimental values than those of the other epimer (Supplementary Table S2). Mean absolute error (MAE) values were 1.70 vs. 2.17 favoring the $(3 R, 4 S, 5 S, 7 S)$ epimer. The signal of the terminal C-12 was neglected, since it has an abnormal shift in the computations due to the truncation. Computed and the experimental ${ }^{13} \mathrm{C}$ NMR chemical shift data in the vicinity of the C-7 chirality center also clearly showed superior agreement for the $(3 R, 4 S, 5 S, 7 S)$ epimer. DP4 + statistical analysis was utilized for the comparison of the experimental and calculated ${ }^{13} \mathrm{C}$ NMR data resulting in $97.31 \%$ confidence for the $(3 R, 4 S, 5 S, 7 S)$ epimer (Smith and Goodman, 2010; Grimblat et al., 2015; Li et al., 2020). Although the experimental SOR value of $\mathbf{2}$ is small, the SOR calculations performed the same way as for $1 \mathbf{m o d}$ were in agreement with the results of the NMR calculation suggesting also $(3 R, 4 S, 5 S, 7 S)$ absolute configuration. The $(3 R, 4 S, 5 S, 7 R)$ epimer of 2 mod gave computed SOR values ranging from +4 to +7 while the $(3 R, 4 S, 5 S, 7 S)$ one in the range from -18 to -23 reproducing better the -21 experimental value of 2 (Supplementary Tables S3, S4). For the TDDFT-ECD method, the same MMFF conformers of $(3 R, 4 S, 5 S, 7 R)$-2 $\mathbf{m o d}$ and $(3 R, 4 S, 5 S, 7 S)$-2 mod were re-optimized at the $\omega$ B97X/TZVP PCM/MeCN level and ECD calculations were performed at various levels. Although both epimers gave rather diverse computed ECD spectra for the individual conformers and Boltzmann populations were small, the average ECD spectra of the $(3 R, 4 S, 5 S, 7 S)$ epimer were found to be similar to the experimental one (Figure 5) in line with the NMR and the SOR calculations. Consequently, the absolute configuration of $\mathbf{2}$ could be elucidated as $(3 R, 4 S, 5 S, 7 S)$.

The molecular formula of compound 3 was assigned as $\mathrm{C}_{19} \mathrm{H}_{33} \mathrm{NO}_{6}$ based on its HRESIMS data, containing an additional oxygen atom when compared to 2 . The NMR data of 3 (Table 1) were similar to those of 2 , except for the presence of an oxygenated methylene group resonating at $\delta_{\mathrm{C}} 63.0$ and $\delta_{\mathrm{H}} 3.54(\mathrm{t})\left(\mathrm{CH}_{2}-20\right)$ and the absence of the terminal methyl group in the side chain. The COSY correlation between $\mathrm{H}_{2}$ $20 / \mathrm{H}_{2}-19\left(\delta_{\mathrm{H}} 1.52\right) / \mathrm{H}_{2}-18\left(\delta_{\mathrm{H}} 1.35\right)$ together with the HMBC correlations from $\mathrm{H}_{2}-20$ to $\mathrm{C}-18\left(\delta_{\mathrm{C}} 26.9\right)$ and $\mathrm{C}-19\left(\delta_{C} 33.7\right)$ indicated the attachment of a hydroxy group at C-20 in the side chain of 3. Detailed analysis of its $2 \mathrm{D}$ NMR spectra revealed that the remaining substructure of $\mathbf{3}$ was identical to that of $\mathbf{2}$. The absolute configuration of $\mathbf{3}$ was identical to that of $\mathbf{2}$ based on their similar ROESY correlations and ECD data.

Aplosporellin C (4) exhibited the same molecular formula as 3 as determined by HRESIMS data. The ${ }^{1} \mathrm{H}$ and ${ }^{13} \mathrm{C}$ NMR data of 4 (Table 2) were likewise similar to those of 3 , yet showed the signal of a doublet methyl group at $\delta_{\mathrm{C}} 23.5$ and $\delta_{\mathrm{H}} 1.14(\mathrm{Me}-20)$ in the side chain and the presence of an oxygenated methine at $\delta_{\mathrm{C}}$ 68.6 and $\delta_{\mathrm{H}} 3.70(\mathrm{CH}-19)$. The COSY correlations between Me$20 / \mathrm{H}-19$, and between $\mathrm{H}-19 / \mathrm{H}_{2}-18\left(\delta_{H} 1.44\right.$ and 1.40$)$ together with the HMBC correlations from Me-20 to C-19 and C-18 $\left(\delta_{C}\right.$ 40.2) indicated the presence of a hydroxy group at C-19 in 4 


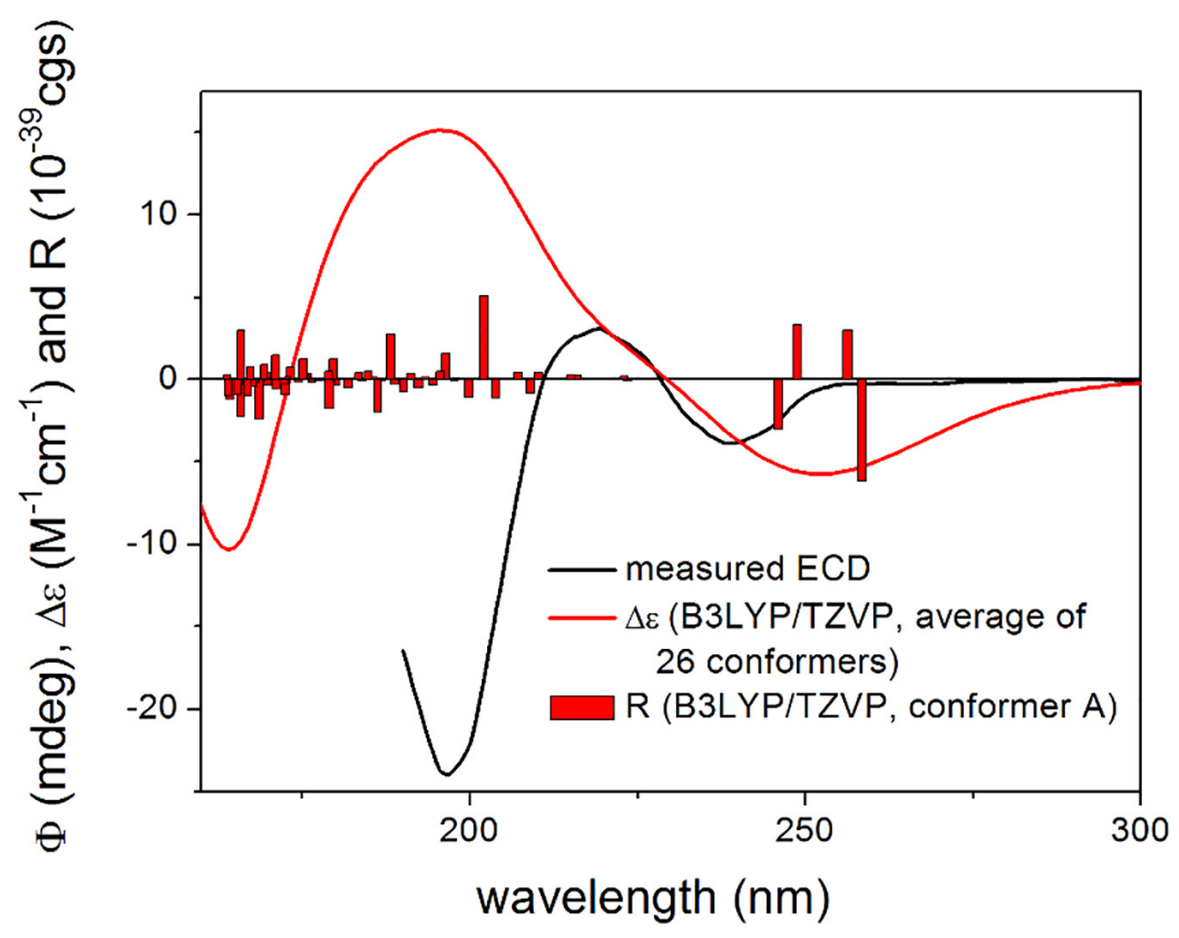

FIGURE 5 | Experimental ECD spectrum of 2 in MeCN compared with the Boltzmann-weighted B3LYP/TZVP PCM/MeCN ECD spectrum of (3R,4S,5S,7S)-2mod. Level of optimization: $\omega$ B97X/TZVP PCM/MeCN. Bars represent the rotatory strength values of the lowest-energy conformer. The experimental spectrum was scaled to the computed one.

instead of C-20 as in $\mathbf{3}$. The remaining substructure of $\mathbf{4}$ was identical to that of $\mathbf{2}$ as confirmed by detailed interpretation of the 2D NMR spectra of 4 . Due to the limited amount, the absolute configuration at C-19 of 4 could not be determined by converting the compound to its Mosher ester.

Compound 5 had the molecular formula $\mathrm{C}_{19} \mathrm{H}_{33} \mathrm{NO}_{7}$ as determined by HRESIMS data, containing one additional oxygen atom when compared to 3 and 4 . Detailed analysis of the 2D NMR of 5 (Table 2) revealed that it was similar to 3 except for the presence of one additional oxygenated methine at $\delta_{\mathrm{C}} 73.3$ and $\delta_{\mathrm{H}} 3.56(\mathrm{CH}-19)$. The signal of the terminal oxygenated methylene at C-20 appeared as two dd peaks in the ${ }^{1} \mathrm{H}$ NMR spectrum of 5 instead of a triplet peak of 3. This suggested that the additional hydroxy group of 5 was located at C-19, which was further confirmed by the COSY correlations between $\mathrm{H}_{2}-20 / \mathrm{H}-19 / \mathrm{H}_{2}-18$ together with the $\mathrm{HMBC}$ correlations from $\mathrm{H}_{2}-20$ to $\mathrm{C}-19$ and $\mathrm{C}$ 18. Thus, compound 5 was elucidated as 19,20-dihydroxy derivative of 2 .

Aplosporellin E (6) was found to have the molecular formula $\mathrm{C}_{21} \mathrm{H}_{35} \mathrm{NO}_{7}$ on the basis of HRESIMS data, requiring five degrees of unsaturation. Comparison of the NMR data (Table 2) indicated compound $\mathbf{6}$ to be closely related to compound 3 except for the presence of an additional methyl group $\left(\delta_{\mathrm{H}} 2.02\right.$ and $\delta_{\mathrm{C}}$ $20.8)$ and an additional carbonyl carbon $\left(\delta_{C} 173.1\right)$. The HMBC correlations from protons of the additional methyl and $\mathrm{H}_{2}-20\left(\delta_{\mathrm{H}}\right.$ $4.05)$ to the additional carbonyl carbon indicated the attachment of an additional acetoxy group at C-20 in $\mathbf{6}$ when compared to 3 .
The molecular formula of compound 7 was the same as $\mathbf{6}$ as deduced from HRESIMS. The ${ }^{1} \mathrm{H}$ and ${ }^{13} \mathrm{C}$ NMR data of 7 (Table 3) were very similar to those of 6, except for the appearance of a terminal methyl group at $\delta_{\mathrm{H}} 1.20(\mathrm{Me}-20)$ which was split into a doublet peak in the ${ }^{1} \mathrm{H}$ NMR spectrum of 7 . Detailed analysis of the HSQC and HMBC spectra revealed an oxygenated methine at $\delta_{\mathrm{C}} 72.4$ and $\delta_{\mathrm{H}} 4.86(\mathrm{CH}-19)$. The COSY correlations between Me-20/H-19/ $\mathrm{H}_{2}-18\left(\delta_{H} 1.58\right.$ and 1.50) together with the HMBC correlations from $\mathrm{H}-19$ and the methyl group at $\delta_{\mathrm{H}} 2.00(3 \mathrm{H}, \mathrm{s})$ to the carbonyl carbon at $\delta_{\mathrm{C}} 172.7$ indicated the presence of an acetoxy group at C-19. Thus, compound 7 was elucidated as 19-O-acetyl derivative of compound 4.

Compound 8 exhibited the molecular formula $\mathrm{C}_{19} \mathrm{H}_{31} \mathrm{NO}_{7}$ as determined by the HRESIMS data. Its ${ }^{1} \mathrm{H}$ and ${ }^{13} \mathrm{C}$ NMR data (Table 3) were similar to those of $\mathbf{2}$ except for that signals of the terminal methyl group in the side chain was replaced with a carbonyl group at $\delta_{\mathrm{C}} 178.1$ (C-20). The HMBC correlations from $\mathrm{H}_{2}-18\left(\delta_{\mathrm{H}} 1.59\right)$ and $\mathrm{H}_{2}-19\left(\delta_{\mathrm{H}} 2.27, \mathrm{t}\right)$ to $\mathrm{C}-20$, together with the COSY correlations between $\mathrm{H}_{2}$ $18 / \mathrm{H}_{2}-19$ indicated a terminal carboxylic acid group in the side chain. The remaining substructure of $\mathbf{8}$ was identical to that of $\mathbf{2}$ as confirmed by detailed analysis of the 2D NMR spectra of $\mathbf{8}$.

The HRESIMS data of $\mathbf{9}$ gave the molecular formula $\mathrm{C}_{20} \mathrm{H}_{33} \mathrm{NO}_{7}$. From the 2D NMR spectra of 9 (Table 3) it was evident that compound 9 was the 20-O-methyl derivative of $\mathbf{8}$ as indicated by the presence of an additional methoxy 
group at $\delta_{\mathrm{H}} 3.65(3 \mathrm{H}, \mathrm{s})$ and $\delta_{\mathrm{C}} 52.0$, together with the HMBC correlations from the methoxy group and $\mathrm{H}_{2}$ $19\left(\delta_{\mathrm{H}} 2.31, \mathrm{t}\right)$ to the carbonyl carbon at $\delta_{\mathrm{C}} 176.1$ (C20).

Aplosporellin I (10) exhibited the molecular formula $\mathrm{C}_{21} \mathrm{H}_{33} \mathrm{NO}_{8}$ as determined by HRESIMS, requiring six degrees of unsaturation. The NMR data of $\mathbf{1 0}$ (Table 4) were similar to those of $\mathbf{8}$ except for the presence of a methyl group $\left(\delta_{\mathrm{H}} 2.07\right.$ and $\left.\delta_{\mathrm{C}} 20.5\right)$ and a carbonyl carbon $\left(\delta_{\mathrm{C}}\right.$ 172.5) in addition to minor differences of the chemical shifts of the protons at the $\gamma$-lactam ring moiety. The COSY correlations between $\mathrm{H}-4\left(\delta_{\mathrm{H}} 4.10\right) / \mathrm{H}-5\left(\delta_{\mathrm{H}} 3.55\right) / \mathrm{H}_{2}-6\left(\delta_{\mathrm{H}} 4.30\right.$ and 4.05$)$ together with the $\mathrm{HMBC}$ correlations from $\mathrm{H}_{2}-6$ and the additional methyl group at $\delta_{\mathrm{H}} 2.07$ to the carbonyl carbon at $\delta_{\mathrm{C}} 172.5$ indicated the attachment of an acetoxy group at C-6. Detailed analysis of the 2D NMR spectra and the ROESY spectra of compound $\mathbf{1 0}$ revealed that the remaining substructure and relative configuration were identical to compound 8. Thus, compound $\mathbf{1 0}$ was identified as the 6-O-acetyl derivative of $\mathbf{8}$.

The molecular formula of $\mathbf{1 1}$ was determined as $\mathrm{C}_{19} \mathrm{H}_{31} \mathrm{NO}_{6}$ based on HRESIMS data, accounting for five degrees of unsaturation. The NMR data of $\mathbf{1 1}$ (Table 4) were similar to those of 2 but exhibited the signal of an additional carbonyl group at $\delta_{C}$ 212.3 (C-19). Moreover, the methyl group in the side chain was shifted to down field at $\delta_{\mathrm{C}} 29.8, \delta_{\mathrm{H}} 2.13(\mathrm{Me}-20)$ and appeared as singlet in the ${ }^{1} \mathrm{H}$ NMR spectrum. The HMBC correlations from Me-20, $\mathrm{H}_{2}-18\left(\delta_{\mathrm{H}} 2.47\right)$ and $\mathrm{H}_{2}-17\left(\delta_{\mathrm{H}} 1.54\right)$ to $\mathrm{C}-19$ indicated the presence of a ketone group in the side chain at C-19 in $\mathbf{1 1}$. The remaining substructure of $\mathbf{1 1}$ was identical to that of $\mathbf{2}$ as confirmed by detailed analysis of the 2D NMR spectra.

On the basis of the HRESIMS data, the molecular formula of 12 was established as $\mathrm{C}_{23} \mathrm{H}_{37} \mathrm{NO}_{8}$ with six degrees of unsaturation. The NMR data of $\mathbf{1 2}$ (Table 4) were similar to those of 6, except for the presence of an additional methyl group $\left(\delta_{\mathrm{H}}\right.$ 2.07 and $\left.\delta_{C} 20.6\right)$ and a carbonyl carbon $\left(\delta_{C} 172.4\right)$. Moreover, the chemical shifts of the protons of the $\gamma$-lactam ring in $\mathbf{1 2}$ were more comparable to those of $\mathbf{1 0}$ rather than $\mathbf{6}$. These findings suggested compound $\mathbf{1 2}$ was a 6-O-acetyl derivative of $\mathbf{6}$, which was confirmed by the HMBC correlations from $\mathrm{H}_{2}-6\left(\delta_{\mathrm{H}} 4.30\right.$ and $\left.\delta_{\mathrm{C}} 4.04\right)$ and the additional methyl group at $\delta_{\mathrm{H}} 2.07$ to the carbonyl carbon at $\delta_{\mathrm{C}} 172.4$.

\section{Bioactivities of the Isolated Compounds}

All isolated compounds were tested for their cytotoxicity against human lymphoma (Ramos) and leukemia (Jurkat J16) cell lines. Pramanicin A (1) exhibited $\mathrm{IC}_{50}$ values of 4.7 and $4.4 \mu \mathrm{M}$ after $24 \mathrm{~h}$ of incubation respectively, whereas after $72 \mathrm{~h}$ of incubation these values were 3.9 and $4.9 \mu \mathrm{M}$, respectively. Treatment with pramanicin A (1) significantly affected cell viability in a dose-dependent manner (Figure 6) whereas the remaining compounds showed no cytotoxicity in these two cell lines in the observed concentration ranging up to $30 \mu \mathrm{M}$. The ketone group at $\mathrm{C}-7$ of pramanicin $\mathrm{A}$ (1) which is conjugated to the olefinic function at C-8/C9 is obviously the key factor responsible for the cytotoxicity against human Ramos and Jurkat J16 cell lines. It was suggested that the $\alpha, \beta$-unsaturated ketone functionality in pramanicin A (1) could be Michael acceptors that can react with a thiol group of cysteine amino acid of proteins or enzymes, and thus causing cytotoxic activity (Amslinger, 2010; Darsih et al., 2015).

In order to evaluate whether the pronounced cytotoxicity of pramanicin A (1) is attributable to the induction of apoptosis, we followed the activation of the effector caspases such as caspase3 in response to pramanicin A (1) treatment. In the Western blot experiment, after $2-8 \mathrm{~h}$ treatment of Ramos and Jurkat J16 cell lines with $10 \mu \mathrm{M}$ pramanicin A (1) respectively, an explicit cleavage of PARP1 (poly [ADP-ribose] polymerase 1) was observed (Figure 7). Cleavage of PARP1, which is a substrate of caspase-3, serves as a surrogate marker for activation of caspase- 3 and therefore indicated that pramanicin A (1) is able to induce apoptosis. Moreover, we also measured caspase- 3 activity by detecting the profluorogenic caspase-3 substrate Ac-DEVDAMC. After treatment with $10 \mu \mathrm{M}$ pramanicin A (1) in the two cell lines, cleavage of Ac-DEVD-AMC was observed within a few hours, which was more obvious in Ramos cells than in Jurkat J16 cells (Figure 8). These results further proved the activation of caspase- 3 and thus induction of apoptosis in Ramos and Jurkat J16 cells by pramanicin A (1).
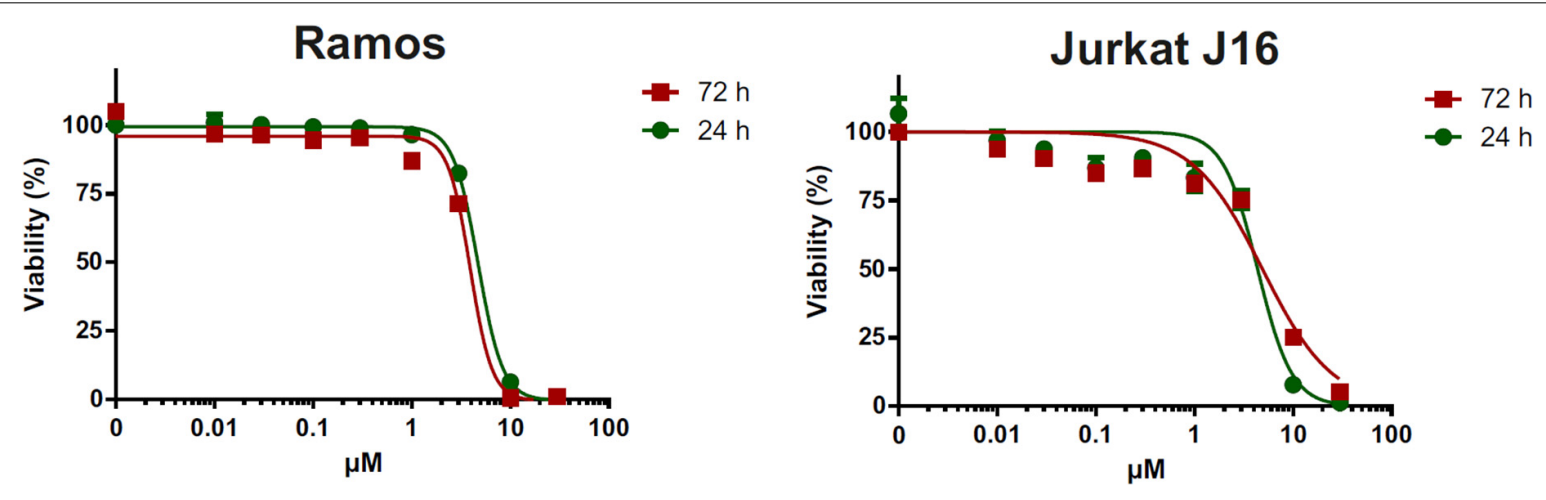

FIGURE 6 | Alamar blue assay of pramanicin A (1) in Ramos and Jurkat J16 cells. Each cell line was treated with 0-300 $\mu \mathrm{M}$ pramanicin A (1) for 24 or 72 h and after incubation, cell viability was evaluated using Alamar blue assay. Results shown are the mean \pm SD from triplicates. 

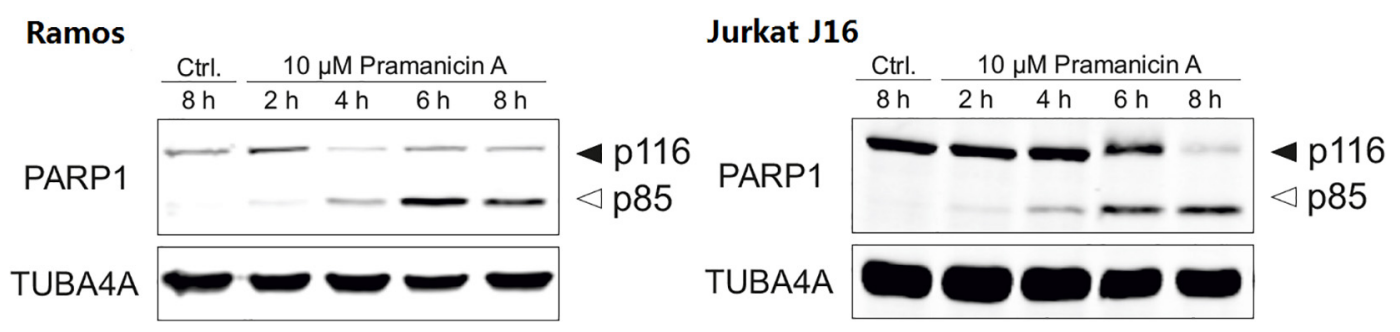

FIGURE 7 | Western blot experiment of pramanicin A (1) in Ramos and Jurkat J16 cells. After incubation for 2-8 h, cleavage of PARP1 was determined. Solid arrowheads indicate the uncleaved form of PARP1, open arrowheads indicate the cleaved form. The expression of TUBA4A was determined as protein loading control. Negative control (Ctrl.) was 0.1\% DMSO.
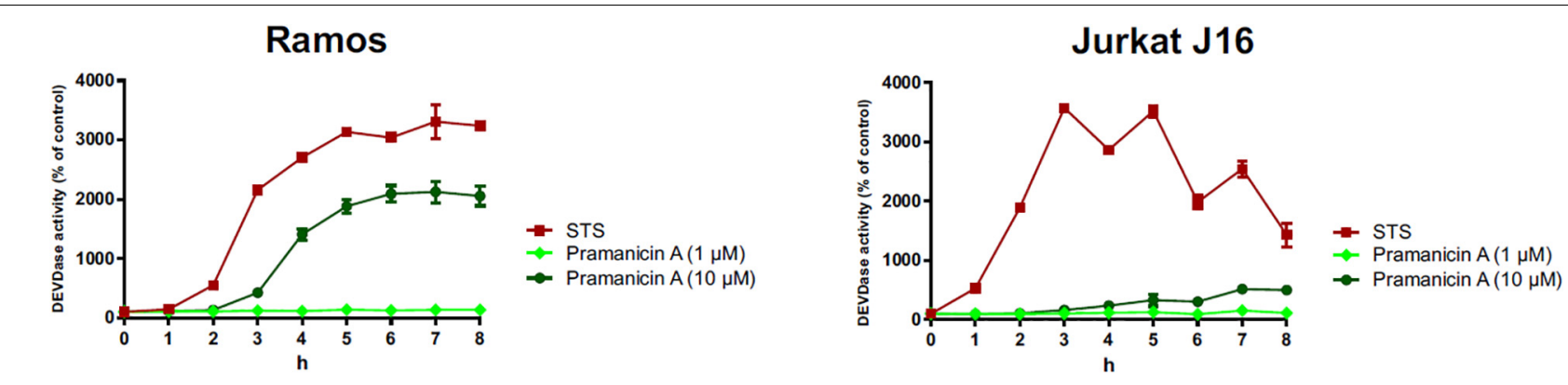

FIGURE 8 | Caspase-3 assay: the kinetics of caspase-3 activation in Ramos and Jurkat J16 cells after treatment with indicated concentrations of pramanicin A (1). Caspase- 3 activity was measured by the rate of cleavage of Ac-DEVD-AMC. Cells treated with staurosporine (STS, $2.5 \mu \mathrm{M})$ were used as positive control. Cells treated with $0.1 \%$ DMSO were used as negative control and set to $100 \%$. Results shown are the mean \pm SD from triplicates.

\section{DISCUSSION}

In the previous biosynthetic study on pramanicin, which differs from pramanicin A (1) by the presence of an epoxide group at C10/C-11 instead of the double bond, in the fungus Stagonospora sp., Duspara et al. (1998) and Harrison et al. (2000) conducted a feeding experiment using ${ }^{2} \mathrm{H},{ }^{13} \mathrm{C},{ }^{15} \mathrm{~N}$, and ${ }^{18} \mathrm{O}$ isotopically labeled precursors. It was concluded that pramanicin originates from one starter molecule acetate and six extender malonates to generate the aliphatic acyl tail, whereas L-serine interacts with one acetate to form the pyrrolidone ring. Acetylation of these two moieties provides 3-acyltetramic acid, followed by a series of oxidation and reduction reactions to form pramanicin (Harrison et al., 2000). Proline or glutamate on the other hand were shown not be precursors of the pyrrolidone moiety (Harrison et al., 1998). In our study, the addition of $3.5 \% \mathrm{NaNO}_{3}$ or of $3.5 \% \mathrm{C}_{5} \mathrm{H}_{8} \mathrm{NNaO}_{4} \cdot \mathrm{H}_{2} \mathrm{O}$ to solid rice medium was found to induce the accumulation of pramanicin-like compounds. Thus, a feeding study using labeled glutamate as a potential precursor of compounds 1-12 would be of interest as a follow up study of this investigation.

\section{CONCLUSION}

In summary, 11 new lactam derivatives, aplosporellins A-K (212), together with the known analog, pramanicin $A(\mathbf{1})$, were isolated from fermentation of $A$. javeedii on solid rice medium with addition of either $3.5 \% \mathrm{NaNO}_{3}$ or $3.5 \%$ monosodium glutamate. All of these compounds were not detected when the fungus was grown on rice medium without these activators. To the best of our knowledge, this study was the first report to regulate secondary metabolites from $A$. javeedii applying an OSMAC approach. The results proved the power of the OSMAC approach on mining new secondary metabolites from endophytic fungi. DFT-NMR, TDDFT-ECD and OR calculations were carried out to determine the absolute configuration. Pramanicin A (1) exhibited strong cytotoxicity against human lymphoma (Ramos) and leukemia (Jurkat J16) cell lines with IC $_{50}$ values of 4.7 and $4.4 \mu \mathrm{M}$, respectively. Furthermore, mechanistic studies indicated that pramanicin A (1) activates caspase- 3 and induces apoptotic cell death.

\section{DATA AVAILABILITY STATEMENT}

The original contributions presented in the study are included in the article/Supplementary Material, further inquiries can be directed to the corresponding authors.

\section{AUTHOR CONTRIBUTIONS}

YG sentence contributed to extraction, isolation, and manuscript preparation. FS, LS, and SW carried out the cytotoxicity assay. $\mathrm{ZG}$ and $\mathrm{KZ}$ contributed to part of structure elucidation. AM and TK performed the DFT-NMR, TDDFT-ECD, and OR 
calculations. ZL and PP supervised the research work and revised the manuscript. All the authors contributed to the article and approved the submitted version.

\section{FUNDING}

This study was supported by the Deutsche Forschungsgemeinschaft (DFG, German Research Foundation) - project number 270650915/GRK 2158 (to PP and SW). PP and YG also want to thank the Jürgen Manchot Foundation for support. The Hungarian authors were supported by the EU and co-financed by the European Regional Development Fund under the project

\section{REFERENCES}

Amslinger, S. (2010). The tunable functionality of $\alpha, \beta$-unsaturated carbonyl compounds enables their differential application in biological systems. ChemMedChem. 5, 351-356. doi: 10.1002/cmdc.200900499

Ancheeva, E., Daletos, G., and Proksch, P. (2018). Lead compounds from mangrove-associated microorganisms. Mar. Drugs. 16:319. doi: 10.3390/ md16090319

Ariantari, N. P., Daletos, G., Mándi, A., Kurtán, T., Müller, W. E. G., Lin, W. H., et al. (2019). Expanding the chemical diversity of an endophytic fungus Bulgaria inquinans, an ascomycete associated with mistletoe, through an OSMAC approach. RSC Adv. 9, 25119-25132. doi: 10.1039/c9ra03678d

Barrett, A. G. M., Head, J., Smith, M. L., Stock, N. S., White, A. J. P., and Williams, D. J. (1999a). Fleming-tamao oxidation and masked hydroxyl functionality: total synthesis of $(+)$-pramanicin and structural elucidation of the antifungal natural product (-)-pramanicin. J. Org. Chem. 64, 6005-6018. doi: 10.1021/ jo9905672

Barrett, A. G. M., Head, J., Smith, M. L., and Stock, N. S. (1999b). Total synthesis of (+)-pramanicin and stereochemical elucidation of the natural product. Chem. Commun. 1999, 133-134. doi: 10.1039/a807988i

Bode, H. B., Bethe, B., Hofs, R., and Zeeck, A. (2002). Big effects from small changes: possible ways to explore nature's chemical diversity. Chembiochem 3, 619-627. doi: 10.1002/1439-7633(20020703)3:7<619::AID-CBIC619<3.0.CO; 2-9

Bohler, P., Stuhldreier, F., Anand, R., Kondadi, A. K., Schlutermann, D., Berleth, N., et al. (2018). The mycotoxin phomoxanthone A disturbs the form and function of the inner mitochondrial membrane. Cell Death Dis. 9:e286. doi: 10.1038/s41419-018-0312-8

Bremond, E., Savarese, M., Su, N. Q., Perez-Jimenez, A. J., Xu, X., Sancho-Garcia, J. C., et al. (2016). Benchmarking density functionals on structural parameters of small-/medium-sized organic molecules. J. Chem. Theory. Comput. 12, 459465. doi: 10.1021/acs.jctc.5b01144

Chai, J. D., and Head-Gordon, M. (2008). Systematic optimization of long-range corrected hybrid density functionals. J. Chem. Phys. 128:084106. doi: 10.1063/1. 2834918

Chen, H., and Harrison, P. H. M. (2004). Investigation of the origin of C2 units in biosynthesis of streptolydigin. Org. Lett. 6, 4033-4036. doi: 10.1021/ol048317h

Cow, C., Valentini, D., and Harrison, P. (1997). Synthesis of the fatty acid of pramanicin. Can. J. Chem. 75, 884-889. doi: 10.1139/v97-106

Daletos, G., Ebrahim, W., Ancheeva, E., El-Neketi, M., Lin, W. H., and Proksch, P. (2017). "Microbial co-culture and OSMAC approach as strategies to induce cryptic fungal biogenetic gene clusters," in Chemical Biology of Natural Products, eds D. J. Newman, G. M. Cragg, and P. G. Grothaus (Boca Raton FL: CRC Press), 233-284. doi: 10.1201/9781315117089-9

Darsih, C., Prachyawarakorn, V., Wiyakrutta, S., Mahidol, C., Ruchirawat, S., and Kittakoop, P. (2015). Cytotoxic metabolites from the endophytic fungus Penicillium chermesinum: discovery of a cysteine-targeted Michael acceptor as a pharmacophore for fragment-based drug discovery, bioconjugation and click reactions. RSC Adv. 5, 70595-70603. doi: 10.1039/C5RA13735G

Duspara, P., Jenkins, S. I., Hughes, D. W., and Harrision, P. H. M. (1998). ). The biosynthesis of pramanicin: intact incorporation of serine and absolute
GINOP-2.3.2-15-2016-00008. TK thanks the National Research Development and Innovation Office (K120181) and AM thanks the János Bolyai Research Scholarship of the Hungarian Academy of Sciences. The Governmental Information-Technology Development Agency (KIFÜ) is acknowledged for CPU time.

\section{SUPPLEMENTARY MATERIAL}

The Supplementary Material for this article can be found online at: https://www.frontiersin.org/articles/10.3389/fmicb. 2020.600983/full\#supplementary-material

configuration of the antibiotic. Chem. Commun. 1998, 2643-2644. doi: 10.1039/ a807401a

Frank, M., Niemann, H., Bohler, P., Stork, B., Wesselborg, S., Lin, W., et al. (2015). Phomoxanthone A-from mangrove forests to anticancer therapy. Curr. Med. Chem. 22, 3523-3532. doi: 10.2174/0929867322666150716115300

Frisch, M. J., Trucks, G. W., Schlegel, H. B., Scuseria, G. E., Robb, M. A., Cheeseman, J. R., et al. (2013). Gaussian 09, Revision E.01. Wallingford, CT: Gaussian, Inc.

Gao, Y., Stuhldreier, F., Schmitt, L., Wesselborg, S., Wang, L., Müller, W. E. G., et al. (2020a). Sesterterpenes and macrolide derivatives from the endophytic fungus Aplosporella javeedii. Fitoterapia 146:104652. doi: 10.1016/j.fitote.2020.104652

Gao, Y., Wang, L., Kalscheuer, R., Liu, Z., and Proksch, P. (2020b). Antifungal polyketide derivatives from the endophytic fungus Aplosporella javeedii. Bioorg. Med. Chem. 28:115456. doi: 10.1016/j.bmc.2020.115456

Grimblat, N., Zanardi, M. M., and Sarotti, A. M. (2015). Beyond DP4: an improved probability for the stereochemical assignment of isomeric compounds using quantum chemical calculations of NMR shifts. J. Org. Chem. 80, 12526-12534. doi: $10.1021 /$ acs.joc.5b02396

Hammerschmidt, L., Aly, A. H., Abdel-Aziz, M., Müller, W. E. G., Lin, W. H., Daletos, G., et al. (2015). Cytotoxic acyl amides from the soil fungus Gymnascella dankaliensis. Bioorg. Med. Chem. 23, 712-719. doi: 10.1016/j.bmc. 2014.12.068

Harrison, P. H. M., Duspara, P. A., Jenkins, S. I., Kassam, S. A., Liscombe, D. K., and Hughes, D. W. (2000). The biosynthesis of pramanicin in Stagonospora sp. ATCC 74235: a modified acyltetramic acid. J. Chem. Soc., Perkin Trans. 2000, 4390-4402. doi: 10.1039/b006007k

Harrison, P. H. M., Hughes, D. W., and William, R. R. (1998). The biosynthesis of pramanicin: origin of the carbon skeleton. Chem. Commun. 1998, 273-274. doi: 10.1039/a706799b

Harwoko, H., Daletos, G., Stuhldreier, F., Lee, J., Wesselborg, S., Feldbrugge, M., et al. (2019). Dithiodiketopiperazine derivatives from endophytic fungi Trichoderma harzianum and Epicoccum nigrum. Nat. Prod. Res. 2019, 1-9. doi: 10.1080/14786419.2019.1627348

Huo, X., Liu, C., Gao, L., Xu, X., Zhu, N., and Cao, L. (2017). Hepatoprotective effect of aqueous extract from the seeds of Orychophragmus violaceus against liver injury in mice and HepG2 cells. Int. J. Mol. Sci. 18:1197. doi: 10.3390/ ijms18061197

Ishii, T., Nonaka, K., Iwatsuki, M., Masuma, R., Ōmura, S., and Shiomi, K. (2012). Virgaricin produced by Virgaria sp. FKI-4860. J. Antibiot. 65, 139-141. doi: 10.1038/ja.2011.123

Ishii, T., Nonaka, K., Sugawara, A., Iwatsuki, M., Masuma, R., Hirose, T., et al. (2015). Cinatrins D and E, and virgaricin B, three novel compounds produced by a fungus, Virgaria boninensis FKI-4958. J. Antibiot. 68, 633-637. doi: 10. 1038/ja.2015.45

Kicsák, M., Mándi, A., Varga, S., Herczeg, M., Batta, G., Bényei, A., et al. (2018). Tricyclanos: conformationally constrained nucleoside analogues with a new heterotricycle obtained from a d-ribofuranose unit. Org. Biomol. Chem. 16, 393-401. doi: 10.1039/c7ob02296d

Kjer, J., Debbab, A., Aly, A. H., and Proksch, P. (2010). Methods for isolation of marine-derived endophytic fungi and their bioactive secondary products. Nat. Protoc. 5, 479-490. doi: 10.1038/nprot.2009.233 
Li, W. S., Yan, R. J., Yu, Y., Shi, Z., Mándi, A., Shen, L., et al. (2020). Determination of the absolute configuration of super-carbon-chain compounds by a combined chemical, spectroscopic, and computational approach: gibbosols A and B. Angew. Chem., Int. Ed. Engl. 59, 13028-13036. doi: 10.1002/anie.202004358

Liu, Y., Stuhldreier, F., Kurtán, T., Mándi, A., Arumugam, S., Lin, W. H., et al. (2017). Daldinone derivatives from the mangrove-derived endophytic fungus Annulohypoxylon sp. RSC Adv. 7, 5381-5393. doi: 10.1039/c6ra27306h

Lodewyk, M. W., Siebert, M. R., and Tantillo, D. J. (2012). Computational prediction of $1 \mathrm{H}$ and $13 \mathrm{C}$ chemical shifts: a useful tool for natural product, mechanistic, and synthetic organic chemistry. Chem. Rev. 112, 1839-1862. doi: $10.1021 / \mathrm{cr} 200106 \mathrm{v}$

MacroModel (2015). SchrödingerLLC. Avaliable online at: https://www. schrodinger.com/MacroModel (accessed June 18, 2020).

Mándi, A., and Kurtán, T. (2019). Applications of OR/ECD/VCD to the structure elucidation of natural products. Nat. Prod. Rep. 36, 889-918. doi: 10.1039/ c9np00002j

Mándi, A., Mudianta, I. W., Kurtán, T., and Garson, M. J. (2015). Absolute configuration and conformational study of psammaplysins A and B from the balinese marine sponge Aplysinella strongylata. J. Nat. Prod. 78, 2051-2056. doi: 10.1021/acs.jnatprod.5b00369

Manns, J., Daubrawa, M., Driessen, S., Paasch, F., Hoffmann, N., Loffler, A., et al. (2011). Triggering of a novel intrinsic apoptosis pathway by the kinase inhibitor staurosporine: activation of caspase-9 in the absence of Apaf-1. FASEB J. 25, 3250-3261. doi: 10.1096/fj.10-177527

Medicinal Plant Images Database (2007). School of Chinese Medicine. Hong Kong: Baptist University.

Pan, R., Bai, X., Chen, J., Zhang, H., and Wang, H. (2019). Exploring structural diversity of microbe secondary metabolites using OSMAC strategy: a literature review. Front. Microbiol. 10:294. doi: 10.3389/fmicb.2019.00294

Pierens, G. K. (2014). 1H and 13C NMR scaling factors for the calculation of chemical shifts in commonly used solvents using density functional theory. J. Comput. Chem. 35, 1388-1394. doi: 10.1002/jcc.23638

Polavarapu, P. L. (2002). Optical rotation: recent advances in determining the absolute configuration. Chirality 14, 768-781. doi: 10.1002/chir.10145

Rehberg, N., Akone, H. S., Ioerger, T. R., Erlenkamp, G., Daletos, G., Gohlke, H., et al. (2018). Chlorflavonin targets acetohydroxyacid synthase catalytic subunit IlvB1 for synergistic killing of Mycobacterium tuberculosis. ACS Infect. Dis. 4, 123-134. doi: 10.1021/acsinfecdis.7b00055

Schwartz, R. E., Helms, G. L., Bolessa, E. A., Wilson, K. E., Giacobbe, R. A., Tkacz, J. S., et al. (1994). Pramanicin, a novel antimicrobial agent from a fungal fermentation. Tetrahedron 50, 1675-1686. doi: 10.1016/s0040-4020(01) 80843-7
Smith, S. G., and Goodman, J. M. (2010). Assigning stereochemistry to single diastereoisomers by GIAO NMR calculation: the DP4 probability. J. Am. Chem. Soc. 132, 12946-12959. doi: 10.1021/ja105035r

Stephens, P. J., and Harada, N. (2010). ECD cotton effect approximated by the Gaussian curve and other methods. Chirality 22, 229-233. doi: 10.1002/chir. 20733

Tan, S. W. B., Chai, C. L. L., and Moloney, M. G. (2014). Synthesis of 3acyltetramates by side chain manipulation and their antibacterial activity. Org. Biomol. Chem. 12, 1711-1716. doi: 10.1039/c4ob00095a

Tan, S. W. B., Chai, C. L. L., and Moloney, M. G. (2017). Mimics of pramanicin derived from pyroglutamic acid and their antibacterial activity. Org. Biomol. Chem. 15, 1889-1912. doi: 10.1039/c6ob02828d

Tan, S. W. B., Chai, C. L. L., Moloney, M. G., and Thompson, A. L. (2015). Synthesis of mimics of pramanicin from pyroglutamic acid and their antibacterial activity. J. Org. Chem. 80, 2661-2675. doi: 10.1021/jo502810b

Tran-Cong, N. M., Mándi, A., Kurtán, T., Müller, W. E. G., Kalscheuer, R., Lin, W. H., et al. (2019). Induction of cryptic metabolites of the endophytic fungus Trichocladium sp. through OSMAC and co-cultivation. RSC Adv. 9, 27279-27288. doi: 10.1039/c9ra05469c

Varetto, U. (2009). MOLEKEL, v. 5.4. Manno: Swiss National Supercomputing Centre.

Wang, H., Dai, H., Heering, C., Janiak, C., Lin, W., Orfali, R. S., et al. (2016). Targeted solid phase fermentation of the soil dwelling fungus Gymnascella dankaliensis yields new brominated tyrosine-derived alkaloids. RSC Adv. 6, 81685-81693. doi: 10.1039/c6ra14554j

Wang, H., Eze, P. M., Höfert, S. P., Janiak, C., Hartmann, R., Okoye, F. B. C., et al. (2018). Substituted l-tryptophan-l-phenyllactic acid conjugates produced by an endophytic fungus Aspergillus aculeatus using an OSMAC approach. RSC Adv. 8, 7863-7872. doi: 10.1039/c8ra00 $200 \mathrm{~b}$

Conflict of Interest: The authors declare that the research was conducted in the absence of any commercial or financial relationships that could be construed as a potential conflict of interest.

Copyright (c) 2020 Gao, Stuhldreier, Schmitt, Wesselborg, Guo, Zou, Mándi, Kurtán, Liu and Proksch. This is an open-access article distributed under the terms of the Creative Commons Attribution License (CC BY). The use, distribution or reproduction in other forums is permitted, provided the original author(s) and the copyright owner(s) are credited and that the original publication in this journal is cited, in accordance with accepted academic practice. No use, distribution or reproduction is permitted which does not comply with these terms. 